\title{
Tectonics
}

\section{Permo-Triassic intermediate-felsic magmatism of the Truong Son belt, eastern margin of Indochina}

\author{
Tran Trong Hoa ${ }^{a}, *$, Tran Tuan Anh ${ }^{a}$, Ngo Thi Phuong ${ }^{a}$, Pham Thi Dung ${ }^{a}$, \\ Tran Viet Anh ${ }^{\mathrm{a}}$, Andrey E. Izokh ${ }^{\mathrm{b}}$, Alexander S. Borisenko ${ }^{\mathrm{b}}$, \\ C.Y. Lan ${ }^{\text {c }}$, S.L. Chung ${ }^{\text {d }}$, C.H. Lo ${ }^{\text {d }}$ \\ ${ }^{a}$ Institute of Geological Sciences, Vietnamese Academy of Science and Technology, 84-Chua Lang, Dong Da, Hanoi, Vietnam \\ ${ }^{\mathrm{b}}$ Institute of Geology and Mineralogy, Siberian Branch of the Russian Academy of Science, \\ Kopchyug pr., 3, 630090, Novosibirsk, Russia \\ ${ }^{\mathrm{c}}$ Institute of Earth Sciences, Academia Sinica, Taipei, Taiwan \\ ${ }^{\mathrm{d}}$ National Taiwan University, Taipei, Taiwan
}

Received 9 August 2007; accepted after revision 12 December 2007

Available online 1 February 2008

Written on invitation of the Editorial Board

\begin{abstract}
Permo-Triassic intermediate-felsic magmatism is developed along the Truong Son fold belt, located in the eastern margin of the Indochina Block. It comprises a succession of the active continental margin associations: calc-alkaline volcano-plutonic associations (272-248 Ma), peraluminous granites (259-245 Ma), and subalkaline felsic volcano-plutonic associations (younger than $245 \mathrm{Ma}$ ). Detailed study of geochemical characteristics such as trace elements (LILE, REE, HFSE) and isotopes (Sr, Nd, Pb) indicates that they are homogeneous and that they are products of the Palaeotethys subduction process in relation to Indochina (IC)/ North Vietnam-South China (NV-SC) amalgamation (S.L. Chung et al., Abstr., GEOSEA 98, Malaysia, 1998, pp. 17-19). The Indosinian characteristics are represented by mantle-crust interaction in magma generation, controlled by their emplacement localities in relation to the Kontum Uplift. The spatial and temporal evolution of Permo-Triassic magmatism allows reconstructing the geodynamic history of the Indosinian orogeny. It confirms that this event ended in Early to Middle Triassic (246-240 Ma, after C. Lepvrier et al., Tectonophysics 393 (2004) 87-118). To cite this article: T.T. Hoa et al., C. R. Geoscience 340 (2007).

(C) 2007 Académie des sciences. Published by Elsevier Masson SAS. All rights reserved.
\end{abstract}

\section{Résumé}

Un magmatisme felsique à intermédiaire d'âge Permo-Triasique s'étend le long de la chaîne de Truong Son, à la marge orientale du bloc Indochinois. Il comprend un ensemble d'associations de type marge continentale active : des associations volcano-plutoniques calcoalcalines (272-248 Ma), des granites peralumineux (259-245 Ma) et des associations volcano-plutoniques felsiques de nature subalcaline (plus jeunes que $245 \mathrm{Ma}$ ). Une étude détaillée de caractéristiques géochimiques comme les éléments traces (LILE, REE, HFSE) et les isotopes ( $\mathrm{Sr}, \mathrm{Nd}, \mathrm{Pb}$ ) révèle leur homogénéité dans le cadre d'une subduction de la Paléotéthys, qui aboutit à la coalescence des blocs Indochine (IC) et Nord Vietnam-Chine du Sud (NV-SC) (S.L. Chung et al., Abstr., GEOSEA 98, Malaysia, 1998, pp. 17-19). La génération de ces magmas est marquée par l'interaction croûte-manteau. L'évolution spatiale et temporelle du magmatisme permo-triasique autorise la reconstruction de l'orogenèse indosinienne. Elle

\footnotetext{
* Corresponding author.

E-mail address: phuongphg@hn.vnn.vn (T.T. Hoa).
} 
confirme que cet événement s'est terminé au Trias inférieur à moyen (260-240 Ma, d'après C. Lepvrier et al., Tectonophysics 393 (2004) 87-118). Pour citer cet article : T.T. Hoa et al., C. R. Geoscience 340 (2007).

(C) 2007 Académie des sciences. Published by Elsevier Masson SAS. All rights reserved.

Keywords: Magmatism; Truong Son belt; Permo-Triassic; Geochemistry

Mots clés : Magmatisme ; Chaîne de Truong Son ; Permo-Trias ; Géochimie

\section{Introduction}

Structurally, the Vietnam's territory belongs to the southeastern part of Eurasia, surrounded by the Sunda active continental margin to the west and the south, and by the Philippine arc to the east. It consists of two geoblocks: the North Vietnam-South China block (or South China block) and the Indochina block. During the Cenozoic, the boundary between them is the AilaoshanRed River shear zone (ASRR). According to recent studies [4,20], the amalgamation occurred in Late Palaeozoic-Early Mesozoic times (mainly in the Permian-Triassic) in the Song Ma Suture zone (Fig. 1).

In the territory of Vietnam, the Indochina Block comprises two major structural units: (1) the Truong Son Late Palaeozoic-Early Mesozoic fold belt or Indosinian orogenic belt; and (2) the Da Lat Late Mesozoic fold belt. The Truong Son fold belt includes the Precambrian Kontum Uplift, overlain by Late Proterozoic-Early to Middle Palaeozoic gneises, amphibolites, schists, migmatites, and lenses of marble as well as Permo-Triassic igneous rocks. These magmatic formations are considered as consequences of the Palaeotethys' closure [38]. The Da Lat fold belt consists of Late Mesozoic (Jurassic-Cretaceous) calc-alkaline to high-K calcalkaline volcano-plutonic associations, which are interpreted as resulting from the subduction of the West Pacific oceanic crust beneath the Southeast Asian continent during the Cretaceous, contemporaneous with the Yanshanian orogeny in the Southeast of China [38].

Permo-Triassic magmatic activities of the Truong Son belt are complex, not only in composition, but also in their appearances. The mainly intermediate-felsic volcano-plutonic rocks are divided into different intrusive complexes and volcanic formations, with different names. This paper provides a brief summary on Permo-Triassic volcano-plutonic associations in the Truong Son belt, as well as on their successive temporal-spatial-compositional evolution.

\section{The Truong Son volcano-plutonic belt}

The Truong Son Palaeozoic orogenic belt (or the Truong Son mountain range) is a NW-SE-oriented range that is elongated from the northwesternmost part of Vietnam to the southeast of the Kontum Uplift (Fig. 1). Within the belt, Late Palaeozoic-Early Mesozoic volcano-plutonic formations are widely distributed. According to compositional characteristics, they are divided into andesite-dacite and calcalkaline granitoid, mafic-ultramafic intrusions, peraluminous granite, trachyrhyolite-monzogranite, and ultrapotassic lamprophyre as well. Similar magmatic rocks are also found outside the belt. For example, andesite is found within the Chau Thoi area, southwest of the Kontum Uplift [19]; Permo-Triassic calcalkaline granites were described in continental shell of southern Vietnam [6,46]. Thus, the Indosinian magmatism is scattered all over the East and Southeast of the Kontum Uplift, and the Late Mesozoic volcanoplutonic associations developed on the 'young' Indosinian basement.

Depending on appearances of the Late PalaeozoicEarly Mesozoic magmatism along the Truong Son belt, three segments are individualized: (1) the northwesternmost segment; (2) the central segment, and (3) the southeastern segment. The sub-longitudinal northwesternmost segment consists of active continental andesite-dacite and calc-alkaline granitoid associations [40,42,43], controlled by the longitudinal Dien Bien-Lai Chau fault zone. The NW-SE-oriented central segment of the Truong Son belt is bounded by the Song Ma fault zone to the north and the Tam Ky-Phuoc Son fault zone to the south (Fig. 1). Peraluminous granite, calcalkaline ultramafic-mafic, dacite-rhyolite and granite-granophyre associations are scattered all over the segment. The southeastern segment consists of the Kontum Uplift and its western and east-southeast margins as well. In this segment, calc-alkaline granitoids, subalkaline volcano-plutonic associations, and potassic-ultrapotassic lamprophyres are widely distributed. Structurally, this segment is an integration of sub-longitudinal and parallel structures, probably due to latter stages (Late Mesozoic and Cenozoic). The presence of Permo-Triassic volcano-plutonic complexes in the Kontum massif indicates its involvement in the Indosinian orogeny. 


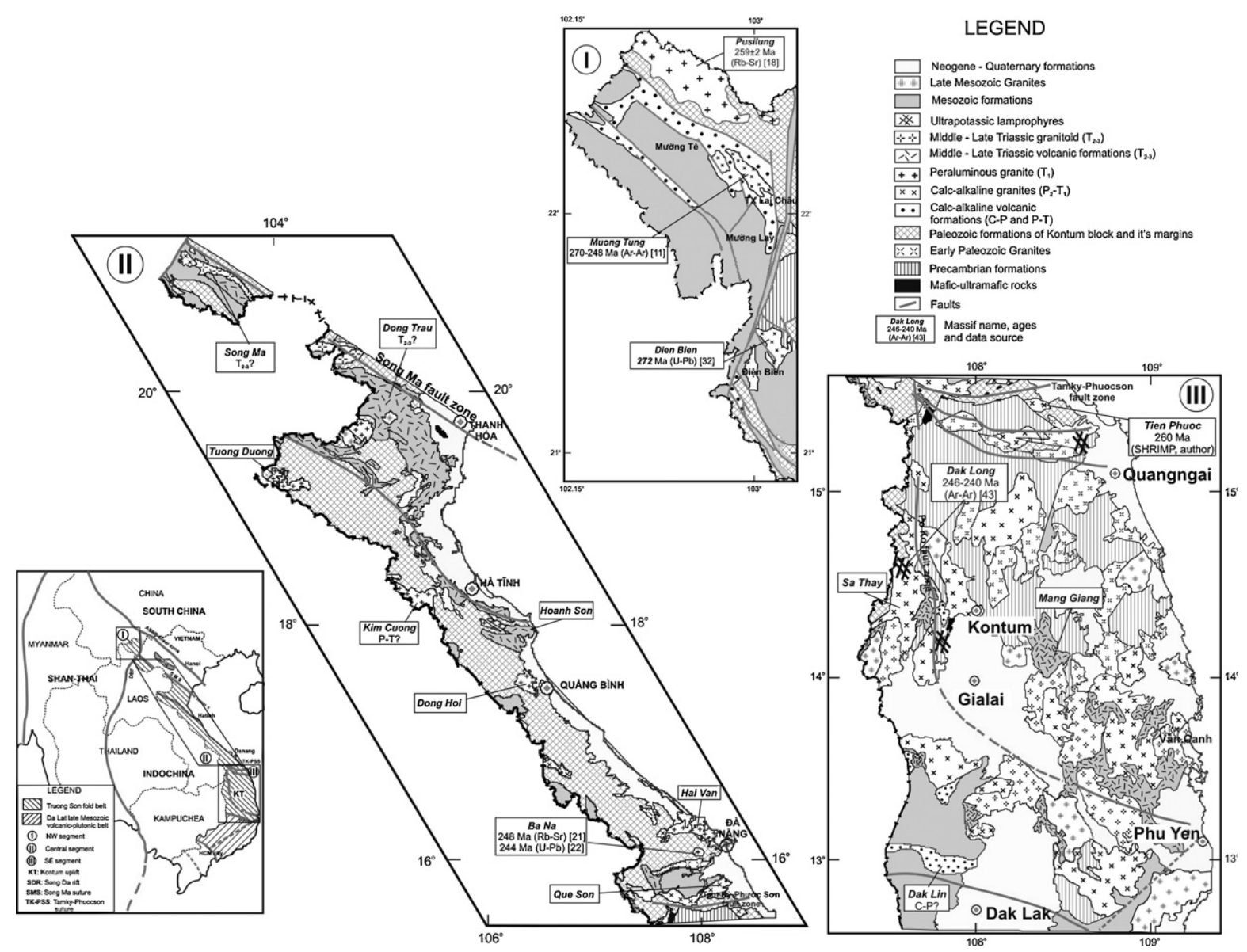

Fig. 1. Distribution of Indosinian magmatic rocks on the Truong Son Fold Belt, and their ages of emplacement. Truong Son Fold Belt: I, northwestern segment; II, central segment; III, southeastern segment.

Fig. 1. Distribution des roches magmatiques indosiniennes dans la chaîne de Truong Son et âges de leur mise en place : I, segment nord-ouest ; II, segment central ; III, segment sud-est.

\section{Andesite-dacite associations}

\subsection{Distribution and age}

Calc-alkaline andesite, dacite and rhyodacite rocks are distributed in two regions: the Song Da upstream and Dien Bien basin in the northwestern segment, and the Dak Lin and Chu Prong areas in the southeastern segment (Fig. 1).

In the northwestern segment, such volcanic rocks belong to the suite of the Permian Song Da formation [7,31], distributed along the sub-longitudinal Lai ChauDien Bien fault zone, and spatially correlated with calcalkaline granitoids (Fig. 1). This volcanic suite comprises mainly andesitodacite and dacite; andesite and andesitic basalt are met. Their Permian ages were determined by the presence of a fauna in limestone, intercalated in terrigenous sediments and tuff of the Song Da Formation
[7,31]. Ar-Ar dating of dacites in this region also shows their Permian-Triassic age (270-248 Ma) [11].

Intermediate-mafic volcanism is spread out in small areas, all over the southern part of Vietnam. A representative stratigraphy of this volcanism cropped out in the Dak Lin area (Fig. 1). In andesitic tuffs, Fusulinida (Pseudofusulina sp., Parafusulina, Bradyna and Schwagerina sp. (?) or Verbeekina sp.) are found, and Astartella lutungini Fedotov, Deltopecten sp. are present in siliceous limestone, which leads to the attribution of a Late Carboniferous-Permian age to this formation [19].

\subsection{Petrography, geochemical and isotopic significances}

Andesites and andesitic basalts are abundant in the Dak Lin area. They are characterized by a porphyric 
texture with pilotaxitic and hyalopilitic groundmass. Weak flow alignments are found. Locally vesicular basalts are met. Plagioclase is a predominant phase (microlite and phenocrystal phase); locally pyroxenes are up to $10-15 \%$. Chloritization, epidotization, and carbonation are common.

Explosive facies consist of tuffs of andesite, andesitic basalt, and a minority of dacite. Pyroclastic and brecciated rocks are common. Pyroclastic materials are glasses, andesitic and basaltic rock fragments, siliciclastic, sandstones, schists, crystal fragments (plagioclase, pyroxene, quartz). Major rock forming phases are clinopyroxene (augite, pigeonite), zoned plagioclase, and magnetite [42].

Geochemically, all rock types belong to the low K- to middle K- calc-alkaline series. The andesitic basalt and andesite have mainly medium silica contents $\left(\mathrm{SiO}_{2}=53-57 \mathrm{wt} . \%\right)$, low magnesium contents

Table 1

Major (wt.\%) and trace element (ppm) abundances in representative samples from the different suites of the Early Permian volcanic associations

Tableau 1

Abondance des éléments majeurs (pourcentage massique) et des éléments traces (ppm) dans des échantillons représentatifs des différentes suites d'associations volcaniques du Permien inférieur

\begin{tabular}{|c|c|c|c|c|c|c|c|c|c|}
\hline Sample & DL $503 / 2$ & DL $503 / 5$ & DL556 & DL533 & T1049/92 & $\mathrm{T} 1053 / 92$ & $\mathrm{~T} 1054 / 92$ & T1056/92 & T1079/92 \\
\hline $\mathrm{SiO}_{2}$ & 74.61 & 76.32 & 56.79 & 54.84 & 69.73 & 66.96 & 57.01 & 58.63 & 52.8 \\
\hline $\mathrm{TiO}_{2}$ & 0.231 & 0.192 & 0.898 & 0.915 & 0.46 & 0.44 & 0.8 & 0.8 & 1.71 \\
\hline $\mathrm{Al}_{2} \mathrm{O}_{3}$ & 12.62 & 11.02 & 15.1 & 17.14 & 14.45 & 15.11 & 17.39 & 16.61 & 13.35 \\
\hline $\mathrm{Fe}_{2} \mathrm{O}_{3}$ & 1.67 & 1.21 & 8.19 & 6.18 & 2.88 & 1.08 & 2.43 & 1.83 & 2.15 \\
\hline $\mathrm{FeO}$ & & & & & 0.51 & 1.92 & 3.99 & 3.99 & 8.88 \\
\hline $\mathrm{MnO}$ & 0.087 & 0.088 & 0.138 & 0.222 & 0.06 & 0.09 & 0.11 & 0.11 & 0.14 \\
\hline $\mathrm{MgO}$ & 0.38 & 0.40 & 2.94 & 2.16 & 0.47 & 2.05 & 3.68 & 3.3 & 2.97 \\
\hline $\mathrm{CaO}$ & 0.89 & 1.53 & 4.67 & 8.21 & 3.61 & 1.47 & 6.76 & 5.31 & 5.83 \\
\hline $\mathrm{Na}_{2} \mathrm{O}$ & 2.93 & 1.31 & 3.91 & 4.8 & 5 & 5.1 & 3.45 & 4.09 & 2.46 \\
\hline $\mathrm{K}_{2} \mathrm{O}$ & 4.56 & 6.17 & 0.71 & 1.33 & 0.69 & 1.58 & 1.13 & 1.56 & 1.43 \\
\hline $\mathrm{P}_{2} \mathrm{O}_{5}$ & 0.031 & 0.030 & 0.225 & 0.214 & 0.17 & 0.14 & 0.27 & 0.26 & 0.31 \\
\hline LOI & 1.84 & 1.51 & 6.1 & 4.35 & 1.63 & 3.96 & 2.87 & 3.23 & 8.49 \\
\hline Total & 99.85 & 99.78 & 99.67 & 100.43 & 99.66 & 99.9 & 99.89 & 99.72 & 100.52 \\
\hline $\mathrm{Rb}$ & 75 & 76 & 15.01 & 35.99 & 12.9 & 40.8 & 31.4 & 44.9 & 70 \\
\hline $\mathrm{Sr}$ & 97 & 55 & 138.78 & 508.46 & 285 & 83 & 492 & 536 & 176 \\
\hline $\mathrm{Y}$ & 61 & 14 & 18.35 & 25.69 & 27.9 & 21 & 18.9 & 18.7 & 25.6 \\
\hline $\mathrm{Zr}$ & 171 & 162 & 73.76 & 94.68 & 170 & 157 & 149 & 150 & 144 \\
\hline $\mathrm{Nb}$ & 7.6 & 8.5 & 2.49 & 3.83 & 8.3 & 7.5 & 9.8 & 9.8 & 11.3 \\
\hline $\mathrm{Ba}$ & 1386 & 1464 & 40.39 & 704.07 & 274 & 258 & 351 & 775 & 278 \\
\hline $\mathrm{La}$ & 40 & 20 & 9.14 & 14.58 & 24.35 & 25.35 & 24.93 & 23.02 & 23.69 \\
\hline $\mathrm{Ce}$ & 53 & 37 & 21.74 & 33.01 & 49.79 & 45.67 & 49.7 & 44.14 & 49.04 \\
\hline $\operatorname{Pr}$ & 8.8 & 4.7 & 2.64 & 4.08 & 6.64 & 5.47 & 5.87 & 5.41 & 6.02 \\
\hline $\mathrm{Nd}$ & 31 & 16 & 13.00 & 18.08 & 26.53 & 21.67 & 23.19 & 21.59 & 23.84 \\
\hline $\mathrm{Sm}$ & 5.8 & 2.5 & 3.10 & 4.06 & 5.56 & 4.12 & 4.39 & 4.12 & 4.95 \\
\hline $\mathrm{Eu}$ & 1.4 & 0.49 & 1.08 & 1.06 & 1.32 & 1.04 & 1.21 & 1.14 & 1.19 \\
\hline $\mathrm{Gd}$ & 6.7 & 2.2 & 3.08 & 4.33 & 5.13 & 4.21 & 4.38 & 3.69 & 4.96 \\
\hline $\mathrm{Tb}$ & 1.1 & 0.31 & 0.48 & 0.69 & 0.83 & 0.59 & 0.68 & 0.58 & 0.8 \\
\hline Dy & 6.7 & 1.9 & 2.95 & 4.15 & 4.85 & 3.19 & 3.76 & 3.45 & 4.94 \\
\hline Но & 1.4 & 0.43 & 0.60 & 0.87 & 1.04 & 0.7 & 0.74 & 0.67 & 1.03 \\
\hline $\mathrm{Er}$ & 4.2 & 1.3 & 1.73 & 2.49 & 2.88 & 1.94 & 1.98 & 1.74 & 2.93 \\
\hline $\mathrm{Tm}$ & & & 0.29 & 0.40 & 0.47 & 0.3 & 0.33 & 0.28 & 0.45 \\
\hline $\mathrm{Yb}$ & 3.8 & 1.7 & 1.72 & 2.53 & 2.87 & 1.94 & 1.82 & 1.73 & 2.73 \\
\hline $\mathrm{Lu}$ & 0.55 & 0.25 & 0.26 & 0.38 & 0.47 & 0.31 & 0.31 & 0.27 & 0.44 \\
\hline $\mathrm{Hf}$ & 4.7 & 3.8 & 2.00 & 2.86 & 4.89 & 4.31 & 4.31 & 3.62 & 3.91 \\
\hline $\mathrm{Ta}$ & 0.72 & 0.56 & 0.19 & 0.26 & 0.47 & 0.59 & 0.74 & 0.7 & 0.85 \\
\hline Th & 20 & 17 & 2.06 & 4.82 & 6.6 & 8.3 & 4.6 & 5.2 & 7.2 \\
\hline $\mathrm{U}$ & 3.8 & 2.8 & 0.52 & 1.18 & 1.9 & 2 & 1.3 & 1.5 & 2 \\
\hline $\mathrm{Th} / \mathrm{Yb}$ & 5.3 & 10 & 1.2 & 0.19 & 2.30 & 4.27 & 2.53 & 3 & 2.6 \\
\hline $\mathrm{Ta} / \mathrm{Yb}$ & 0.19 & 0.34 & 0.11 & 0.10 & 0.16 & 0.30 & 0.41 & 0.40 & 0.31 \\
\hline $\mathrm{Nb} / \mathrm{U}$ & 2 & 3 & 4.7 & 3.2 & 4.3 & 3.7 & 7.5 & 6.5 & 5.6 \\
\hline
\end{tabular}

Dak Lin area (SW): DL 503/2, DL 503/5 - rhyolite, DL 556, DL 533 - andesitodacite. Muong Tung area (NW): T1049/92, T1053/92 - dacite, T1054/92, T1056/92 - andesitodacite, T1079/92 - andesite. 

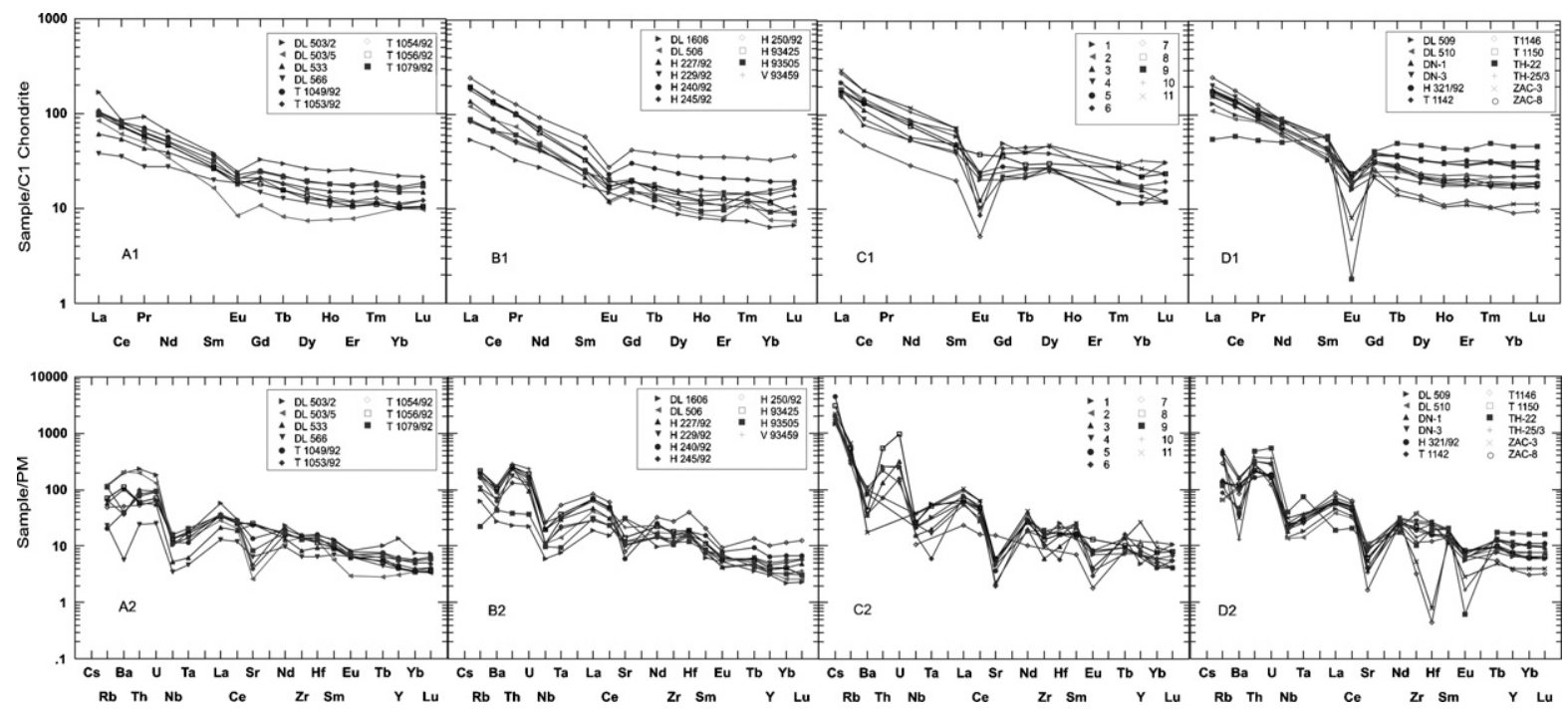

Fig. 2. Chondrite-normalized REE pattern and mantle-normalized spidergrams [27] of the Indosinian magmatic rocks: A-1-2, andesite-dacite associations; B-1-2, calc-alkaline granitoids; C-1-2, syn-collision peraluminous granites; D-1-2, post-collision volcano-plutonic associations. Sample index in Fig. 2 from Tables 1-4.

Fig. 2. Diagrammes REE normalisés aux chondrites et graphes normalisés au manteau [27] des roches magmatiques indosiniennes : A-1-2, associations andésite-dacite ; B-1-2, granitoïdes calco-alcalins ; C-1-2, granites peralumineux syn-collision ; D-1-2, associations volcanoplutoniques post-collision. Les numéros d'échantillons de la Fig. 2 proviennent des Tableaux 1 à 4 .

$(\mathrm{MgO}=2.16-3.7 \mathrm{wt} . \%)$, medium to low titanium contents $\left(\mathrm{TiO}_{2}=0,8-1.7 \mathrm{wt} . \%\right)$, medium to high total alkaline species contents $\left(\mathrm{K}_{2} \mathrm{O}+\mathrm{Na}_{2} \mathrm{O}=3.9-6.1 \mathrm{wt} . \%\right)$, and are sodium rich $\left(\mathrm{K}_{2} \mathrm{O} / \mathrm{Na}_{2} \mathrm{O}=0.1-0.3 \mathrm{wt} . \%\right)$ (Table 1). The felsic rocks are dacite to rhyolite (Fig. 2, Table 1) with $\mathrm{SiO}_{2}=68.7-76$ wt. $\%,\left(\mathrm{Na}_{2} \mathrm{O}+\right.$ $\left.\mathrm{K}_{2} \mathrm{O}\right)=5.6-7.4$ wt.\%, and are sodium rich, with $\mathrm{K}_{2} \mathrm{O}$ / $\mathrm{Na}_{2} \mathrm{O}=0.34-0.75$ for dacite and 1.5-4.7 for rhyolite (Table 1). Both types share the same fractionated differentiation trends, represented by an increase in the silica and potassium contents and a decrease in the $\mathrm{Al}, \mathrm{Ti}$, $\mathrm{P}$, and $\mathrm{Mg}$ contents (Table 1). This feature is also shown by an increase of $\mathrm{Zr}$ and $\mathrm{Nd}$, coupled with a decrease of $\mathrm{Sr}$ along with an increase of silica (Table 1).

The intermediate-mafic and felsic rocks have the same REE concentrations and REE distribution patterns (Table 1, Fig. 2-1). They are enriched with LREE and have flat HREE patterns, relative to $\mathrm{C}_{1}$ chondrite [27], with $4.88<(\mathrm{La} / \mathrm{Yb})_{\mathrm{N}}<9.07$, with a medium-weak negative $\mathrm{Eu}$ anomaly $\left(\mathrm{Eu} / \mathrm{Eu}^{*}=0.57\right.$ to 0.67$)$, which may indicate that plagioclase was not removed from the magma. Such patterns are found in the low- to medium$\mathrm{K}$ calc-alkaline rocks of the active continental margin.

In primitive-mantle normalized spidergrams, all samples yield similar patterns, with depletion of high field strength elements (e.g., Nb, Ta, Zr, and Ti, Fig. 2-2). High concentrations of large ion lithophile elements $(\mathrm{Cs}, \mathrm{Rb}, \mathrm{Th}, \mathrm{U}$, and $\mathrm{K}$ ) are coupled with pronounced depletion in $\mathrm{Sr}$ and $\mathrm{P}$. Their trace-element patterns normalized to Ocean Ridge Granite (ORG, [23]) show generally similar shapes, marked by a variable enrichment in $\mathrm{Rb}$ and $\mathrm{Th}$ and a depletion of $\mathrm{Ta}, \mathrm{Nb}, \mathrm{Hf}$, and $\mathrm{Zr}$ [42]. The andesitodacites have a smoother pattern, with a lower differentiation pattern, but represent negative anomalies of $\mathrm{Ta}, \mathrm{Nb}$, and $\mathrm{Ce}$, which may indicate a strong contamination by pelagic sediments. Essentially, andesite and dacite of the Dak Lin area are similar as regards their $\mathrm{Nb}$, La, and Ce contents, in comparison with similar rock types of the Dien Bien-Lai Chau area.

Isotopic data are listed in Table 5. The isotopic ratios of mafic and felsic rocks are relatively different. The mafic series are characterized by homogenous isotopic ratios with ${ }^{87} \mathrm{Sr} /{ }^{86} \mathrm{Sr}(\mathrm{i})=0.70563-0.70731$; ${ }^{143} \mathrm{Nd} /{ }^{144} \mathrm{Nd}(\mathrm{i})=0.51288-0.51296$, similar to andesitic basalts of active continental margins (Table 5, Fig. 3). Dacite and rhyolite display ${ }^{87} \mathrm{Sr} /{ }^{86} \mathrm{Sr}(\mathrm{i})=0.70643-$ $0.70706 ;{ }^{143} \mathrm{Nd} /{ }^{144} \mathrm{Nd}(\mathrm{i})=0.51251-0.51214$ with $\varepsilon_{\mathrm{Nd}(T)}$ varying from -5.27 to 2.06 (Table 5, Fig. 3). The volcanic rocks are characterized by relatively homogeneous lead isotopic ratios: ${ }^{206} \mathrm{~Pb} /{ }^{204} \mathrm{~Pb}=18.52-18.91$, ${ }^{207} \mathrm{~Pb} /{ }^{204} \mathrm{~Pb}=15.52-15.63,{ }^{208} \mathrm{~Pb} /{ }^{204} \mathrm{~Pb}=38.38-39.15$ (Table 5, Fig. 4), which are lower than those encountered in typical arc-volcanic rocks, but similar to those from the active continental margin. The $T_{\mathrm{DM}}$ age of the rock varies from 0.58 to $1.40 \mathrm{Ga}$. The similarity of their geochemical features implies that they were derived from similar 

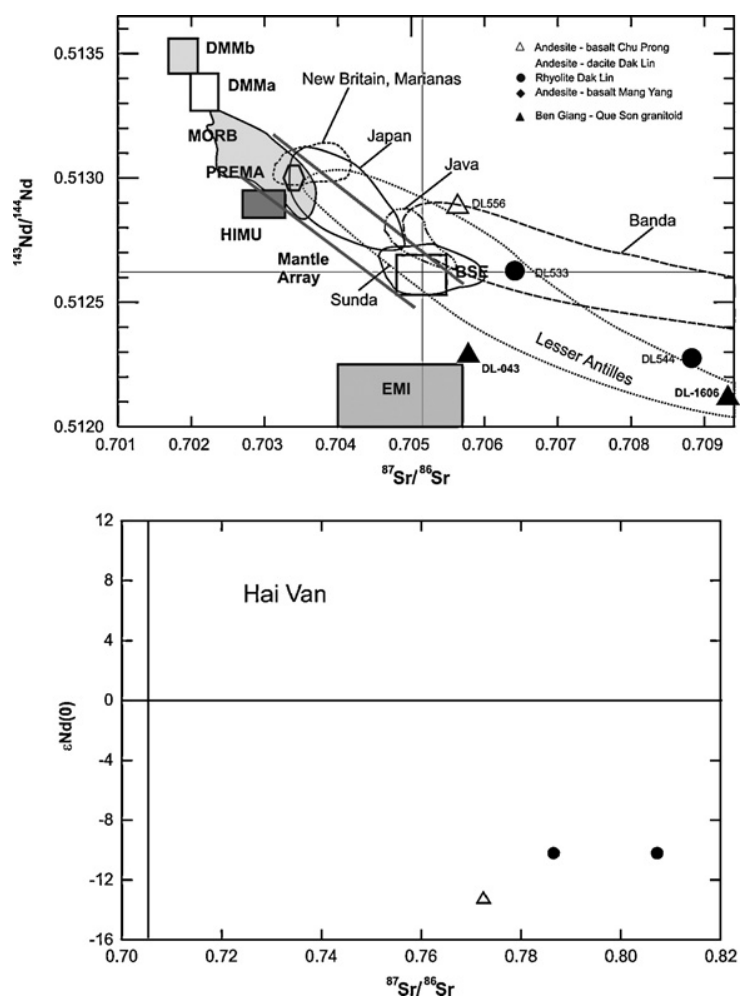

Fig. $3 .{ }^{87} \mathrm{Sr} /{ }^{86} \mathrm{Sr}$ versus ${ }^{143} \mathrm{Nd} /{ }^{144} \mathrm{Nd}$ correlation diagrams of the Indosinian magmatic rocks. Data from Table 5. Fields after Wilson [49].

Fig. 3. Diagrammes de corrélation ${ }^{87} \mathrm{Sr} /{ }^{86} \mathrm{Sr}$ versus ${ }^{143} \mathrm{Nd} /{ }^{144} \mathrm{Nd}$ des roches magmatiques indosiniennes. Données du Tableau 5. Champs définis selon Wilson [49].

mantle wedge-derived sources, but with various degrees of differentiation.

\subsection{Source characteristics}

The high LREE, low HREE concentrations, and relatively flat REE distribution patterns in all samples imply that they were derived from a shallower source, in which garnet is absent.

Source contamination by sediment-derived fluxes from the subducting slab at the mantle wedge was also important. Positive LILE spikes are shown in Fig. 2. Moreover, negative anomalies of HFS elements such as $\mathrm{Ta}, \mathrm{Nb}, \mathrm{Ti}, \mathrm{Hf}$, and $\mathrm{Zr}$ represent the contribution of pelagic sediment to the subduction environment $[29,30]$.

$\mathrm{The} \mathrm{Nb} / \mathrm{U}$ ratios of the rocks (2-7.5) are much lower than those of the continental crust are, implying that the enrichment in $\mathrm{U}$ relative to $\mathrm{Nb}$ could not be produced by any normal mixing process between the mantle and crustal sources. It can only be explained by a contribution of a subducted slab-derived fluid. Coupled
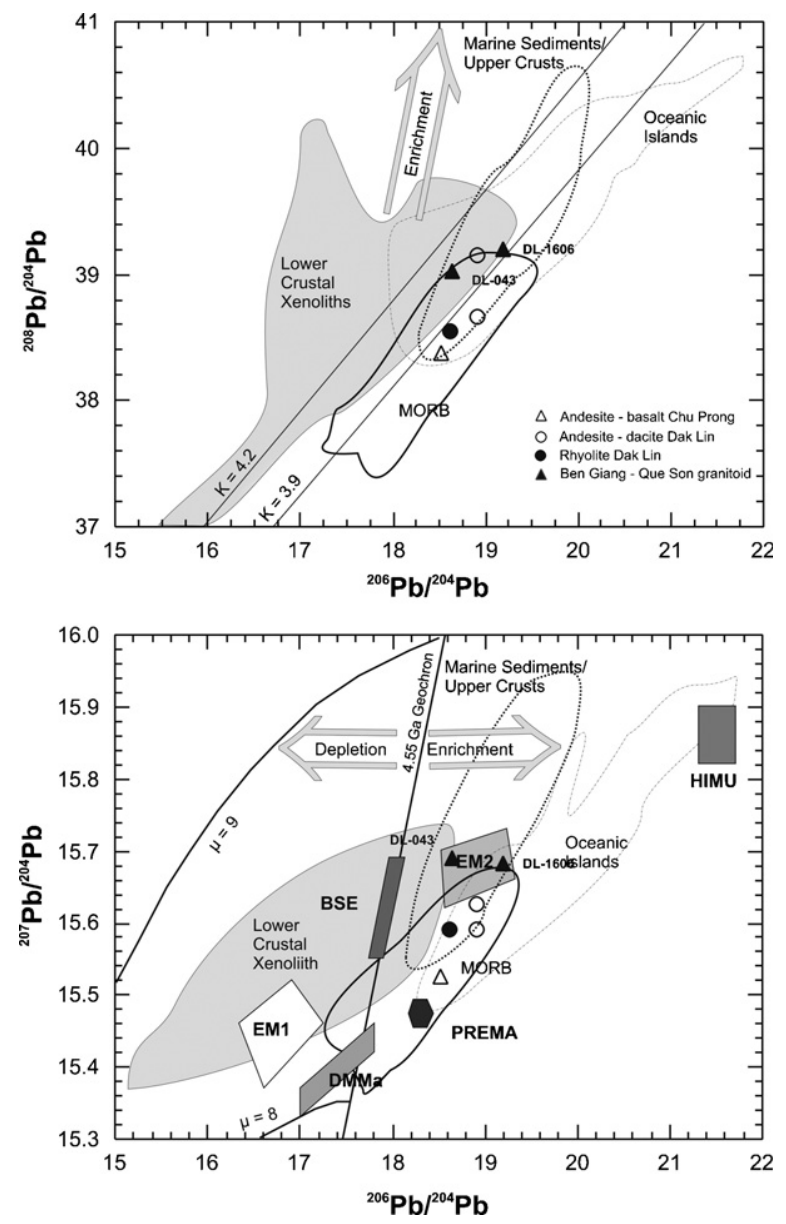

Fig. 4. ${ }^{208} \mathrm{~Pb} /{ }^{204} \mathrm{~Pb}$ and ${ }^{207} \mathrm{~Pb} /{ }^{204} \mathrm{~Pb}$ versus ${ }^{206} \mathrm{~Pb} /{ }^{204} \mathrm{~Pb}$ correlation diagrams of the Indosinian magmatic rocks. Data from Table 5.

Fig 4. Diagrammes de corrélation ${ }^{208} \mathrm{~Pb} /{ }^{204} \mathrm{~Pb}$ et ${ }^{207} \mathrm{~Pb} /{ }^{204} \mathrm{~Pb}$ versus ${ }^{206} \mathrm{~Pb} /{ }^{204} \mathrm{~Pb}$ des roches magmatiques indosiniennes. Données du Tableau 5.

with the $\mathrm{U}$ concentration, high $\mathrm{Th} / \mathrm{Yb}(2-10)$ and medium $\mathrm{Ta} / \mathrm{Yb}(0.1-0.4)$ ratios strongly exhibit that the surveyed rocks are of active continental margin environment. This feature is also indicated by higher $\mathrm{Zr}$ and $\mathrm{Hf}$ concentrations than in MORB, showing a difference with arc-derived rocks. Their variations also indicate the predominant fractionated differentiation in the formation of the rocks.

\section{Calc-alkaline granitoids}

\subsection{Distribution and age}

Calc-alkaline granitoids are distributed all over the three segments of the Truong Son belt, but they are more 
abundant in the northwestern and southeastern segments.

In the northwestern segment, granitoid intrusions (Dien Bien complex) are exposed along the Dien BienLai Chau fault zone (Fig. 1). The rock types are diorite, granodiorite, amphibole (hornblende)-biotite granite, in which diorites are considered as the earliest stages of the intrusions. Their Permian-Triassic ages were determined by their stratigraphic correlation with the Song Da formation and overlain by Late Triassic terrigenous sediments $[7,45]$. The ages of granodiorite and amphibole-biotite granite are 266-252 Ma (Rb-Sr)

Table 2

Major (wt.\%) and trace element (ppm) abundances in representative samples from the different intrusive rock suites of the Permian-Triassic calcalkaline granitoid associations

Tableau 2

Abondance des éléments majeurs (pourcentage massique) et des éléments traces (ppm) dans des échantillons représentatifs des différentes suites de roches intrusives composant les associations de granitoïdes calco-alcalins du Permo-Trias

\begin{tabular}{|c|c|c|c|c|c|c|c|c|c|c|}
\hline Sample & H227/92 & H229/92 & H240/92 & H245/92 & $\mathrm{H} 250 / 92$ & H93505 & V93459 & H93425 & DL 1606 & DL 506 \\
\hline $\mathrm{SiO}_{2}$ & 65.23 & 63.12 & 72.57 & 64 & 71.21 & 52.61 & 65.49 & 71.31 & 51.24 & 72.78 \\
\hline $\mathrm{TiO}_{2}$ & 0.44 & 0.48 & 0.23 & 0.52 & 0.35 & 0.8 & 0.69 & 0.39 & 0.758 & 0.263 \\
\hline $\mathrm{Al}_{2} \mathrm{O}_{3}$ & 15.61 & 15.77 & 13.95 & 15.44 & 13.41 & 19.96 & 15.5 & 13.83 & 18.6 & 13.83 \\
\hline $\mathrm{Fe}_{2} \mathrm{O}_{3}$ & 1.87 & 1.96 & 1.45 & 1.9 & 0.78 & 8.55 & 4.59 & 3.68 & 8.59 & 2.08 \\
\hline $\mathrm{FeO}$ & 2.91 & 3.42 & 1.64 & 3.18 & 2.56 & & & & & \\
\hline $\mathrm{MnO}$ & 0.13 & 0.15 & 0.05 & 0.11 & 0.07 & 0.18 & 0.06 & 0.05 & 0.156 & 0.037 \\
\hline $\mathrm{MgO}$ & 1.81 & 2.23 & 0.41 & 2 & 0.66 & 3.22 & 1.88 & 0.93 & 5.87 & 0.67 \\
\hline $\mathrm{CaO}$ & 4.91 & 5.37 & 1.47 & 4.59 & 2.02 & 8.69 & 3.09 & 1.37 & 10.26 & 1.72 \\
\hline $\mathrm{Na}_{2} \mathrm{O}$ & 3.45 & 3.28 & 3.46 & 3.17 & 3.17 & 4.43 & 3.38 & 2.25 & 2.34 & 2.9 \\
\hline $\mathrm{K}_{2} \mathrm{O}$ & 1.71 & 2.36 & 3.91 & 2.7 & 3.81 & 0.78 & 3.88 & 4.43 & 1.22 & 4.74 \\
\hline $\mathrm{P}_{2} \mathrm{O}_{5}$ & 0.12 & 0.2 & 0.06 & 0.14 & 0.11 & 0.28 & 0.21 & 0.14 & 0.17 & 0.061 \\
\hline LOI & 1.86 & 1.41 & 1.04 & 1.91 & 1.54 & 0.7 & 1.09 & 1.28 & 1.04 & 0.64 \\
\hline Total & 100.05 & 99.75 & 100.24 & 99.66 & 99.69 & 99.9 & 99.85 & 99.66 & 100.27 & 99.8 \\
\hline $\mathrm{Rb}$ & 64.4 & 68.5 & 122 & 104.2 & 107 & 14 & 135 & 139 & 39.27 & 107.84 \\
\hline $\mathrm{Sr}$ & 220 & 216 & 125 & 253 & 171 & 647 & 456 & 295 & 622.96 & 251.12 \\
\hline $\mathrm{Y}$ & 17.6 & 23.4 & 30 & 21.5 & 46 & 15 & 15 & 19 & 13.91 & 15.06 \\
\hline $\mathrm{Zr}$ & 121 & 151 & 179 & 132 & 308 & 127 & 189 & 205 & 21.28 & 190.3 \\
\hline $\mathrm{Nb}$ & 8 & 7.9 & 14.1 & 7.6 & 19 & 6.97 & 19 & 14 & 4.28 & 7.76 \\
\hline $\mathrm{Ba}$ & 330 & 467 & 662 & 445 & 754 & 297 & 824 & 755 & 192.27 & 595.9 \\
\hline $\mathrm{La}$ & 32.47 & 19.98 & 45.95 & 19.92 & 57.6 & 21 & 43 & 46 & 12.8 & 28.92 \\
\hline $\mathrm{Ce}$ & 55.21 & 40.61 & 85.05 & 41.87 & 106.61 & 41 & 78 & 82 & 26.91 & 54.48 \\
\hline $\operatorname{Pr}$ & 5.8 & 4.76 & 9.73 & 5.04 & 12.18 & 5.8 & 9.8 & 9.6 & 3.12 & 7.03 \\
\hline $\mathrm{Nd}$ & 20.4 & 19.06 & 34.16 & 19.59 & 43.35 & 22 & 32 & 30 & 13 & 23.45 \\
\hline $\mathrm{Sm}$ & 3.34 & 3.88 & 6.82 & 3.9 & 8.97 & 3.7 & 5.1 & 5 & 2.74 & 3.79 \\
\hline $\mathrm{Eu}$ & 0.71 & 0.9 & 1.34 & 0.99 & 1.6 & 1.2 & 1.1 & 1 & 0.87 & 0.68 \\
\hline $\mathrm{Gd}$ & 3.25 & 3.92 & 6.27 & 3.98 & 8.69 & 3.3 & 4.2 & 4.1 & 2.55 & 3.05 \\
\hline $\mathrm{Tb}$ & 0.53 & 0.68 & 1.02 & 0.65 & 1.47 & 0.47 & 0.54 & 0.62 & 0.39 & 0.5 \\
\hline Dy & 2.98 & 3.76 & 6.11 & 3.93 & 9.11 & & & & 2.23 & 2.55 \\
\hline Ho & 0.65 & 0.88 & 1.21 & 0.79 & 1.99 & 0.54 & 0.67 & 0.7 & 0.45 & 0.5 \\
\hline $\mathrm{Er}$ & 1.81 & 2.44 & 3.49 & 2.32 & 5.79 & 1.6 & 1.8 & 2.1 & 1.25 & 1.37 \\
\hline $\mathrm{Tm}$ & 0.37 & 0.37 & 0.52 & 0.37 & 0.87 & 0.31 & 0.27 & 0.31 & 0.19 & 0.3 \\
\hline $\mathrm{Yb}$ & 2.06 & 2.67 & 3.34 & 2.5 & 5.62 & 1.6 & 1.6 & 2 & 1.1 & 1.31 \\
\hline $\mathrm{Lu}$ & 0.36 & 0.45 & 0.5 & 0.42 & 0.93 & 0.23 & 0.27 & 0.23 & 0.17 & 0.19 \\
\hline $\mathrm{Hf}$ & 4.69 & 5.03 & 5.71 & 5.01 & 12.21 & 3.7 & 4.9 & 5.9 & 0.87 & 4.25 \\
\hline $\mathrm{Ta}$ & 1.21 & 0.85 & 1.29 & 0.91 & 2.18 & 0.39 & 1.4 & 1.5 & 0.31 & 0.57 \\
\hline Th & 20.6 & 14.6 & 20.3 & 11 & 21.6 & 3.2 & 24 & 22 & 1.95 & 20.81 \\
\hline $\mathrm{U}$ & 2 & 2.6 & 3.2 & 2.5 & 3.6 & 0.78 & 5 & 4 & 0.46 & 2.61 \\
\hline $\mathrm{Th} / \mathrm{Yb}$ & 10 & 5.46 & 6.07 & 4.40 & 3.84 & 2 & 15 & 11 & 1.77 & 15.88 \\
\hline $\mathrm{Ta} / \mathrm{Yb}$ & 0.58 & 0.32 & 0.38 & 0.36 & 0.38 & 0.24 & 0.87 & 0.75 & 0.28 & 0.43 \\
\hline $\mathrm{Nb} / \mathrm{U}$ & 4 & 3 & 4.4 & 3 & 5.2 & 8.9 & 3.8 & 3.5 & 9.30 & 2.97 \\
\hline
\end{tabular}

NW segment: Massif Nam Meng: H227/92, H229/92 - granodiorite, H240/92 - biotite-hornblende granite. Massif Muong Tung: H245/92 granodiorite. Massif Dien Bien: H250/92 - biotite-hornblende granite. Central segment: massif Que Son: H93505 - gabbro-diorite, V93459 granodiorite, H93425 - biotite-hornblende granite. DL1606 - gabbro-diorite on the HCM Road (western Kontum uplift), DL506 - biotitehornblende granite, Chu Prong area, southwestern Kontum uplift). 
[7] and $272 \mathrm{Ma}(\mathrm{U}-\mathrm{Pb})$ [33]. According to [33], several individual diorite bodies in this region yield ages from 415 to $430 \mathrm{Ma}$, which are considered of an older magmatism stage, and they are not included in this paper.

Diorite, granodiorite, and granite intrusions of the southeastern segments are distributed in the Kontum Uplift and in its northern and western margins (the Ben Giang-Que Son complex). At the northern margin of the Kontum Uplift, calc-alkaline granitoids form large massifs, along the Permo-Triassic latitudinal ductile deformation zones [14]. Due to the Indosinian tectonic activities, the rocks are locally deformed. The SHRIMP age of zircon from Tien Phuoc granite (Ben Giang-Que Son complex) is $260 \pm 4 \mathrm{Ma}$, corresponding to the Late Permian (our unpublished data). At the western margin, in the Sa Thay area of the Kontum Uplift, similar granitoids are found. However, in this region, porphyritic granites are more abundant [38]. Noteworthy features are the widespread calc-alkaline mafic lamprophyres (kersantite, sperssartite) and porphyrite coupled with granitoids. This is a typical feature of active continental margin magmatism.

\subsection{Petrography, geochemical and isotopic significances}

The calc-alkaline granitoids are mainly diorite, granodiorite and amphibole-biotite granite, in which granodiorite is predominant. They are porphyritic rocks with large plagioclase and/or K-feldspar megacrysts (up to $2-4 \mathrm{~cm}$ in size). Major minerals are plagioclase + quartz + K-feldspar + biotite + amphibole, with different amounts. Accessory minerals are titanite, apatite, zircon, locally orthite. Leucogranites are rare. Porphyritic granites form small intrusions and dykes that are distributed mainly at the western margin of the Kontum Uplift (Sa Thay area).

Biotites in granitoids are high in $\mathrm{Ti}\left(\mathrm{TiO}_{2}=2.5-\right.$ 3.5 wt.\%), $\mathrm{Mg}(\mathrm{MgO}=7.5$ wt.\% in diorite, 12.5 wt.\% in granodiorite), and low in $\mathrm{Al}\left(\mathrm{Al}_{2} \mathrm{O}_{3}=14\right.$.9$15.3 \mathrm{wt} . \%)$. It is a typical feature of biotite in calcalkaline and high-K calc-alkaline granitoids [34]. After these authors, amphiboles are high-magnesium hornblendes, tschemakitic hornblende and magnesium hastingsite with various $\mathrm{MgO}$ contents (from 5.83 to 12.30 wt.\%). Contrary to the $\mathrm{MgO}$ content, the $\mathrm{FeO}$ contents of amphibole and biotite tend to increase from diorite to granite, indicating magmatic differentiation.

Calc-alkaline granitoids have low to medium alkalinity, are sodium-rich or $\mathrm{K}-\mathrm{Na}$ rich; some are potassium-rich monzogranites (Table 2). Diorite, granodiorite and granite of the Dien Bien and Ben Giang-Que Son complexes are identical in concentrations and distribution patterns of trace elements such as $\mathrm{Rb}, \mathrm{Sr}, \mathrm{Ba}, \mathrm{Zr}, \mathrm{Nb}, \mathrm{Ta}, \mathrm{Th}, \mathrm{U}$, as well as REE (Table 2, Fig. 2-B1-2). Gabbrodiorite and diorite are characterized by flat REE patterns with $8.35<(\mathrm{La} / \mathrm{Yb})_{\mathrm{N}}<9.41$, weak negative Eu anomalies $\left(\mathrm{Eu} / \mathrm{Eu}^{*}=0.99-1.03\right.$, Fig. 2-B-1), whilst quartz diorite and granodiorite present steep patterns, with higher concentration of LREE $\left(5.06<(\mathrm{La} / \mathrm{Yb})_{\mathrm{N}}<19.28\right)$, neat Eu negative anomalies $\left(\mathrm{Eu} / \mathrm{Eu}^{*}=0.1-0.71\right)$. The differences in element concentrations between intermediate and felsic rocks might represent a magmatic differentiation. Their trace elements and REE patterns, especially depletions of $\mathrm{Nb}$, $\mathrm{Ta}$, and $\mathrm{Zr}$ (Fig. 2-B1-2), are similar to active continental margin granitoids.

The Permo-Triassic granitoids are characterized by various $\mathrm{Sr}$ isotopic ratios $\left({ }^{86} \mathrm{Sr} /{ }^{87} \mathrm{Sr}=0.7058\right.$ to 0.7101$)$, coupled with homogenous $\mathrm{Nd}$ isotopic ratio $\left({ }^{143} \mathrm{Nd} /\right.$ ${ }^{144} \mathrm{Nd}=0.512304-0.512489, \quad \varepsilon_{\mathrm{Nd}}=0.48$ to -4.45$)$, showing that they were strongly contaminated by crustal material (Table 5, Fig. 3). Lead isotopic ratios are relatively homogenous $\left({ }^{206} \mathrm{~Pb} /{ }^{204} \mathrm{~Pb}=18.678_{-}^{-}\right.$ $19.138,{ }^{207} \mathrm{~Pb} /{ }^{204} \mathrm{~Pb}=15.678-15.684,{ }^{208} \mathrm{~Pb} /{ }^{204} \mathrm{~Pb}=$ 38.978-39.145) (Table 5, Fig. 4), and similar to EM2; they also indicate strongly crustal contamination. Their $T_{\mathrm{DM}}$ modal ages give a crustal resident age of 1.03-1.50 Ga. $\mathrm{Sr}, \mathrm{Nd}$, and $\mathrm{Pb}$ isotopic significances of the Permo-Triassic granitoids are relatively close to the above-mentioned Permian volcanic rocks, implying that they were both derived from similar mantle wedge sources above the subduction slab. However, crustal signatures are identical in Permo-Triassic granitoids. Decreasing $\mathrm{Nb} / \mathrm{U}$ ratios from gabbrodiorite (9.3) to granite (2.9) also indicate the increase of crustal contamination from intermediate to felsic rocks.

\section{Early Triassic syn-collision peraluminous granites}

\subsection{Distributions and ages}

Permo-Triassic peraluminous granites are scattered in all three segments of the Truong Son belt, especially in the central segment. They consist of large intrusions, such as Muong Lat, Tuong Duong to the north, Kim Cuong, Dong Hoi, and Hai Van to the south of the central segment. Small intrusions of similar peraluminous granite are also found in the Kontum Uplift. Among these intrusions, the Hai Van and $\mathrm{Ba} \mathrm{Na}$ massifs in the North of Kontum Uplift are investigated in detail. In previous researches, these 
granites were grouped into different complexes: for instance the Pu Si Lung, Muong Lat, Kim Cuong, Dong Hoi intrusions were grouped into the Late Triassic Phia Bioc granite complex [7], or the Carboniferous biotite-muscovite granites of the Truong Son complex [45]. In the Geological Map of Vietnam, scale 1:500,000, the Kim Cuong and Dong Hoi intrusions belong to the Truong Son complex, whilst other intrusions are associated with the Phia Bioc complex to the north, and the Hai Van complex to the south [5,32]. The U-Pb, Rb-Sr and $\mathrm{Ar}-\mathrm{Ar}$ isotopic ages of biotite granite and of two-mica granite of the $\mathrm{Ba} \mathrm{Na}$ intrusions are $248-245 \mathrm{Ma}$ $[21,22]$. Biotite granite of the Pu Si Lung intrusion in the northwestern segment was dated from the Late Permian (259 Ma, Rb-Sr, after [18]).

Table 3

Major (wt.\%) and trace element (ppm) abundances in representative samples of the Triassic peraluminous granites

Tableau 3

Abondance des éléments majeurs (pourcentage massique) et des éléments traces (ppm) dans des échantillons représentatifs des granites peralumineux triasiques

\begin{tabular}{|c|c|c|c|c|c|c|c|c|c|c|c|}
\hline Sample & 1 & 2 & 3 & 4 & 5 & 6 & 7 & 8 & 9 & 10 & 11 \\
\hline $\mathrm{SiO}_{2}$ & 67.68 & 71.88 & 75.59 & 67.68 & 71.35 & 75.22 & 62.91 & 71.88 & 74.66 & 72.71 & 76.07 \\
\hline $\mathrm{TiO}_{2}$ & 0.68 & 0.42 & 0.15 & 0.58 & 0.48 & 0.09 & 0.06 & 0.3 & 0.24 & 0.27 & 0.05 \\
\hline $\mathrm{Al}_{2} \mathrm{O}_{3}$ & 14.35 & 13.26 & 12.81 & 14.65 & 13.45 & 12.77 & 17.48 & 13.56 & 12.43 & 13.28 & 12.77 \\
\hline $\mathrm{Fe}_{2} \mathrm{O}_{3}{ }^{*}$ & 5.84 & 3.55 & 1.84 & 5.28 & 3.84 & 2.19 & 2.55 & 2.79 & 2.61 & 2.63 & 1.45 \\
\hline $\mathrm{MnO}$ & 0.07 & 0.08 & 0.04 & 0.09 & 0.05 & 0.08 & 0.13 & 0.04 & 0.05 & 0.04 & 0.11 \\
\hline $\mathrm{MgO}$ & 1.75 & 0.92 & 0.36 & 2.07 & 1.11 & 0.47 & 0.13 & 0.27 & 0.27 & 0.32 & 0.13 \\
\hline $\mathrm{CaO}$ & 1.67 & 1.43 & 1.16 & 1.16 & 1.54 & 0.91 & 2.41 & 1.57 & 1.26 & 1.1 & 0.51 \\
\hline $\mathrm{Na}_{2} \mathrm{O}$ & 2.49 & 2.23 & 2.26 & 1.6 & 2.43 & 2.15 & 4.23 & 3 & 2.97 & 2.82 & 3.73 \\
\hline $\mathrm{K}_{2} \mathrm{O}$ & 3.84 & 4.74 & 4.7 & 4.27 & 4.08 & 4.75 & 7.82 & 5.19 & 4.57 & 5.65 & 4.3 \\
\hline $\mathrm{P}_{2} \mathrm{O}_{5}$ & 0.14 & 0.15 & 0.13 & 0.12 & 0.14 & 0.08 & 0.03 & 0.09 & 0.08 & 0.38 & 0.14 \\
\hline LOI & 1.33 & 1.18 & 0.82 & 1.83 & 1.21 & 0.93 & 2.32 & 0.91 & 0.73 & 0.85 & 0.65 \\
\hline Total & 100 & 99.9 & 99.9 & 99.3 & 99.7 & 99.6 & 100.09 & 99.59 & 99.82 & 100.05 & 99.9 \\
\hline $\mathrm{Ba}$ & 567 & 594 & 246 & 758 & 577 & 258 & & 307 & 162 & 683 & 121 \\
\hline $\mathrm{Rb}$ & 250 & 252 & 290 & 214 & 209 & 179 & & 338 & 375 & 245 & 418 \\
\hline $\mathrm{Sr}$ & 105 & 99.6 & 46.8 & 97 & 76.5 & 41 & 320 & 126 & 198 & 108 & 123 \\
\hline $\mathrm{Zr}$ & 201 & 156 & 66.8 & 210 & 191 & 121 & & 145 & 150 & 164 & 104 \\
\hline $\mathrm{Hf}$ & 6.5 & 7.7 & 3 & 5 & & 1.8 & & 5 & 5 & & \\
\hline $\mathrm{Nb}$ & 16 & 18 & 11 & 17 & 15 & 11 & 7.5 & 18.5 & 17.8 & 26 & 27.2 \\
\hline $\mathrm{Ta}$ & 1.3 & 2.3 & 0.8 & 0.7 & & 0.24 & & 2.1 & 2.4 & & \\
\hline Th & 22 & 21.7 & 11 & 18 & & 6 & & 46 & 44 & & \\
\hline $\mathrm{U}$ & 5.2 & 5.4 & 6.6 & 2.8 & & 3.2 & & 20 & 26 & & \\
\hline $\mathrm{Y}$ & 22 & 33 & 32 & 33 & & 38 & & 46 & 53 & 54 & 118 \\
\hline Cs & 11.5 & 16 & 13 & 14.9 & 34 & 13.2 & & 24.2 & 18 & 14.6 & 17 \\
\hline $\mathrm{Li}$ & 72 & 58.1 & 19 & 80.7 & 8 & 33 & 9 & 65.8 & 64 & 50 & 18.6 \\
\hline $\mathrm{Be}$ & 1 & 2.8 & & 3.5 & 34 & 8.5 & & 7.4 & 3.2 & 0.8 & 12.5 \\
\hline Sn & & & & & & & 16 & 5.1 & 8.6 & & 8.7 \\
\hline $\mathrm{La}$ & 52 & 39 & 43 & 37 & 42 & 52 & 16 & 44 & 18 & 65 & 70 \\
\hline $\mathrm{Ce}$ & 84 & 48 & 70 & 56 & 80 & 90 & 29 & 82 & 22 & 110 & 110 \\
\hline $\mathrm{Nd}$ & 41 & 25 & 27 & 25 & 38 & 40 & 13.6 & 36 & 12.5 & 50 & 55 \\
\hline $\mathrm{Sm}$ & 9 & 6.3 & 7.5 & 6 & 7.5 & 10.3 & 3.1 & 7 & 1.2 & 11 & 11 \\
\hline $\mathrm{Eu}$ & 1.4 & 1.2 & 1.3 & 0.6 & 1.4 & 0.5 & 0.3 & 2.2 & 2.2 & 0.7 & 0.7 \\
\hline Gd & 10.3 & 4.2 & & 4.5 & 5.8 & 9 & 4.5 & 7.5 & 0.6 & 8 & 8 \\
\hline $\mathrm{Tb}$ & 1.5 & 0.8 & 1 & 0.8 & 1 & 1.7 & 0.9 & 1.1 & 7.8 & 1.5 & 1.5 \\
\hline Dy & 10 & 7 & 7 & 6.3 & 6.9 & 11.7 & 6.8 & 7.7 & & 10 & 12 \\
\hline $\mathrm{Tm}$ & 0.7 & 0.3 & & & 0.3 & 0.5 & & 0.7 & 0.7 & 0.7 & 0.8 \\
\hline $\mathrm{Yb}$ & 3.8 & 2 & 2.7 & 2.3 & 2 & 3 & 2.9 & 3.8 & 4.8 & 5.6 & 4.6 \\
\hline $\mathrm{Lu}$ & 0.8 & 0.4 & 0.3 & 0.3 & 0.3 & 0.5 & 0.4 & 0.6 & 0.8 & 0.8 & 0.6 \\
\hline $\mathrm{Th} / \mathrm{Yb}$ & 5.79 & 10.85 & 4.07 & 7.82 & & 2 & & 12.10 & 9.16 & & \\
\hline $\mathrm{Ta} / \mathrm{Yb}$ & 0.34 & 1.15 & 0.29 & 0.30 & & 0.08 & & 0.55 & 0.50 & & \\
\hline $\mathrm{Nb} / \mathrm{U}$ & 3.07 & 3.33 & 1.66 & 6.07 & & 3.43 & & 0.92 & 0.68 & & \\
\hline
\end{tabular}

Massifs: Hai Van: 1, granodiorite $(n=3) ; 2$, biotite and 2-mica granites $(n=32) ; 3$, leucogranites $(n=4)$ - Son Tra: 4, granodiorite $(n=4) ; 5$, biotite and 2-mica granites $(n=14) ; 6$, muscovite granite and aplite $(n=3)-B a \mathrm{Na}$ : 7, high-K granite $(n=3) ; 8$, biotite and 2-mica granites $(n=4)$; 9 , leucogranite $(n=5)$; Tra My: 10, biotite granite $(n=3), 11$, leucogranite $(n=6) . n$ : number of analyses. 
5.2. Petrography, geochemical and isotopic significances

The Permo-Triassic peraluminous granites are mainly biotite and two-mica granites. However, granodiorite and rarely diorite are locally met. The rocks are characterized by a porphyric texture with megacrysts of plagioclase and/or K-feldspar. Biotite is a major mineral phase in all intrusions. The biotites have high $\mathrm{Al} \quad\left(\mathrm{Al}_{2} \mathrm{O}_{3}=16.77-17.32\right.$ wt. $\left.\%\right)$ and $\mathrm{Ti}$ $\left(\mathrm{TiO}_{2}=2.94-3.88\right.$ wt.\%) contents, low $\mathrm{Mg}$ contents $(\mathrm{MgO}=4.2-7.8$ wt.\%), relatively high $\mathrm{F}$ contents (0.77-0.94 wt.\%), and low $\mathrm{Cl}$ contents (0.030.08 wt.\%) [34]. Other aluminous mineral phases are muscovite, silimanite, and cordierite. Locally, in leucogranite, garnets are met.

The chemical compositions of the Hai Van and $\mathrm{Ba}$ Na peraluminous granites (Table 3) show that the rock vary from intermediate type $\left(\mathrm{SiO}_{2}=62.9-67.68 \mathrm{wt} . \%\right)$ to typical granite $\left(\mathrm{SiO}_{2}=71.35-74.66 \mathrm{wt} . \%\right)$ and leucogranite $\left(\mathrm{SiO}_{2}=75.22-76.07 \mathrm{wt} . \%\right)$. The rocks are characterized by medium alkalinity, some samples from the $\mathrm{Ba} \mathrm{Na}$ intrusion have high alkalinity (up to $11 \mathrm{wt} . \%)$, probably due to feldspathization associated with greisenization.

Biotite granites are enriched with $\mathrm{Rb}$, Th, U, LREE, depleted in $\mathrm{Ba}, \mathrm{Sr}, \mathrm{Zr}, \mathrm{Nb}$, Ta. Two-mica granites are enriched with $\mathrm{Li}, \mathrm{Be}, \mathrm{Sn}$ (Table 3). Chondrite-normalized REE patterns show strongly negative Eu anomalies, coupled with flat HREE (Fig. 2-C1). On the primitive mantle normalized spidergrams (Fig. 2-C2), the rocks present negative anomalies of $\mathrm{Ba}, \mathrm{Nb}, \mathrm{Ta}, \mathrm{Sr}$, and $\mathrm{Zr}$, which are typical features of the Permo-Triassic magmatism in the Truong Son belt [38]. Coupled with them are peaks of $\mathrm{U}, \mathrm{Th}$, and $\mathrm{Pb}$. In comparison to Permian calc-alkaline granites that were described previously, they share the same distribution pattern, in spite of different concentrations.

Isotopic data of peraluminous granites are listed in Table 5. The ${ }^{87} \mathrm{Sr} /{ }^{86} \mathrm{Sr}$ ratios of the Hai Van, Ba Na, and Tra My intrusions are high (0.75026-0.80728), implying they were melted from old crystalline crust that has high $\mathrm{Rb} / \mathrm{Sr}$ ratio. Initial ${ }^{143} \mathrm{Nd} /{ }^{144} \mathrm{Nd}$ ratios are relatively homogeneous $(0.511958-0.512116)$, with $\varepsilon_{\mathrm{Nd}(0)}=$ -13.3 for the Hải Vân intrusion and -10.2 for the Ba $\mathrm{Na}$ and Tra My intrusions (Table 5). Their crustal resident ages (1.8-2.23 Ga) imply that they were melted from a mature continental crust [25,38]. These characteristics are quite different from those of the Late Mesozoic peraluminous granites of the Da Lat volcano-plutonic belt, located to the south-southeast of the Kontum Uplift, which have lower ${ }^{87} \mathrm{Sr} /{ }^{86} \mathrm{Sr}$ ratios
$(0.7055-0.7072)$ and higher $\varepsilon_{\mathrm{Nd}(T)}$ values $(-2.02$ and 2.06) [38].

\section{Middle Triassic post-collision alkaline magmatism}

\subsection{Distribution and age}

Middle Triassic post-collision volcano-plutonic associations are widely distributed in the central and southeastern segments. They are mainly volcanic to hypabyssal (sub-volcanic) formations; intrusions are merely met. The boundaries between hypabyssal and overlain extrusive layers are undistinguishable. At the northern part of the central segment, volcano-plutonic associations form NW-SE-oriented narrow bands, from Sam Nua (Laos), crossing Song Ma (along the Song Ma ophiolite belt) to Deo Ngang-Hoanh Son (Fig. 1), which were named the Sam Nua-Hoanh Son belt $[20,45]$. The volcanic rocks were grouped into the Dong Trau Formation, while hypabyssal and intrusive rocks were grouped in the Song Ma Complex [5]. Volcanoplutonic rocks of the southeastern segment were formed in wide fields or bands in the Kontum Uplift, in which volcanic rocks belong to the Mang Yang Formation, whilst hypabyssal and intrusive rocks belong to the Van Canh Complex [5,19]. Middle Triassic ages of volcanic and associated granite-granophyres are based on the isotope dating Ma after different authors (see below).

\subsection{Petrography, geochemical and isotopic significances}

Middle Triassic volcanic rocks are mainly porphyric dacite, rhyodacite, and rhyolite with plagioclase, Kfeldspar, and quartz phenocrysts, felsite, and/or glassy groundmass. Extrusive rocks are predominant. Associated hypabyssal and intrusive rocks are granophyre granite with 'graphic' texture, minor granodiorite and diorite, especially in the Van Canh complex. Biotite and amphibole are common. Typical accessory mineral phase of the Van Canh formation is fluorite.

Dacite, rhyolite, and granophyre granite of Song Ma, Hoanh Son and Mang Yang belong to medium to low alkaline series with fluctuated $\mathrm{K}_{2} \mathrm{O} / \mathrm{Na}_{2} \mathrm{O}$ ratios, from a sodium-rich variety (Song Ma) to a potassium-rich one (Hoanh Son). In the Mang Yang formation, sodium-rich varieties are concentrated on the western margin of the Kontum Uplift, while potassium-rich varieties are found in its centre. However, dacites, rhyolites, and granophyre granites of different areas are quite similar in trace elements and REE characteristics (Table 4, 
Table 4

Major (wt.\%) and trace element (ppm) abundances in representative samples from the different intrusive rock suites of the Middle-Late Triassic post-collision association

Tableau 4

Abondance des éléments majeurs (pourcentage massique) et des éléments traces (ppm) dans des échantillons représentatifs des différentes suites de roches intrusives composant l'association post-collisionnelle du Trias moyen-supérieur

\begin{tabular}{|c|c|c|c|c|c|c|c|c|c|c|c|c|}
\hline Sample & TH-22 & TH-25/3 & DL 509 & DL 510 & DN-1 & DN-3 & T1142 & T1146 & T1150 & H321/92 & ZAC-3 & ZAC-8 \\
\hline $\mathrm{SiO}_{2}$ & 74.55 & 76.11 & 70.35 & 68.89 & 72.54 & 71.60 & 61.69 & 74.22 & 62.34 & 75.73 & 72.83 & 68.77 \\
\hline $\mathrm{TiO}_{2}$ & 0.07 & 0.11 & 0.486 & 0.502 & 0.49 & 0.55 & 0.92 & 0.16 & 0.99 & 0.17 & 0.14 & 0.39 \\
\hline $\mathrm{Al}_{2} \mathrm{O}_{3}$ & 12.13 & 11.53 & 15.06 & 14.95 & 12.66 & 13.16 & 15.5 & 13.57 & 15.19 & 12.75 & 12.8 & 13.39 \\
\hline $\mathrm{Fe}_{2} \mathrm{O}_{3}$ & 0.90 & 1.26 & 2.98 & 4.19 & 3.20 & 3.61 & 6.45 & 2.08 & 6.62 & 1.84 & 1.54 & 3.18 \\
\hline $\mathrm{MnO}$ & 0.01 & 0.01 & 0.079 & 0.157 & 0.04 & 0.04 & 0.09 & 0.02 & 0.05 & 0.02 & 0.03 & 0.06 \\
\hline $\mathrm{MgO}$ & 0.03 & 0.05 & 0.60 & 0.81 & 0.69 & 0.69 & 2.6 & 0.37 & 3.36 & 0.07 & 0.05 & 0.55 \\
\hline $\mathrm{CaO}$ & 1.25 & 0.12 & 1.12 & 1.59 & 1.03 & 1.55 & 4.34 & 0.2 & 2.41 & 1.12 & 0.37 & 1.22 \\
\hline $\mathrm{Na}_{2} \mathrm{O}$ & 7.68 & 2.25 & 4.99 & 3.98 & 1.97 & 2.24 & 4.1 & 4.34 & 3.18 & 4.14 & 2.99 & 3.01 \\
\hline $\mathrm{K}_{2} \mathrm{O}$ & 0.09 & 6.93 & 2.81 & 2.99 & 5.76 & 4.94 & 1.28 & 3.3 & 2.78 & 2.73 & 5.43 & 4.87 \\
\hline $\mathrm{P}_{2} \mathrm{O}_{5}$ & 0.02 & 0.02 & 0.124 & 0.030 & 0.15 & 0.15 & 0.21 & 0.04 & 0.22 & 0.02 & 0.03 & 0.12 \\
\hline LOI & 0.35 & 0.35 & 1.29 & 1.74 & 0.92 & 0.88 & & & & 0.94 & 4.3 & 4.3 \\
\hline Total & 97.080 & 98.740 & 99.89 & 99.83 & 99.450 & 99.410 & 97.18 & 98.3 & 97.14 & 99.45 & 100.05 & 99.86 \\
\hline $\mathrm{Rb}$ & 0.725 & 249.9 & 42 & 41 & 305.8 & 257.1 & 55.75 & 91.82 & 79.8 & 86 & 280 & 180 \\
\hline $\mathrm{Sr}$ & 194.6 & 69.43 & 226 & 229 & 116.7 & 164.8 & 183.42 & 35.36 & 130.64 & 88 & 77 & 210 \\
\hline $\mathrm{Y}$ & 77.15 & 30.96 & 29 & 33 & 51.05 & 52.25 & 30.86 & 36.13 & 33.25 & 44 & 18 & 17 \\
\hline $\mathrm{Zr}$ & 112.4 & 160.9 & 403 & 422 & 277.3 & 301. & 210.42 & 128.31 & 242.54 & 216 & 60 & 36 \\
\hline $\mathrm{Nb}$ & 28.06 & 17.84 & 10 & 9.6 & 13.19 & 13.74 & 16.21 & 14.17 & 17.08 & 15.7 & 22.4 & 14.8 \\
\hline $\mathrm{Ba}$ & 270.9 & 93.06 & 815 & 716 & 1129. & 1028. & 323.78 & 719.45 & 855.26 & 718 & 215 & 591 \\
\hline $\mathrm{La}$ & 13.07 & 39.63 & 31 & 26 & 43.78 & 48.84 & 37.72 & 42.82 & 41.44 & 41.92 & 37.36 & 59.8 \\
\hline $\mathrm{Ce}$ & 36.12 & 82.47 & 61 & 55 & 89.33 & 96.65 & 73.69 & 85.5 & 84.76 & 84.03 & 76.47 & 111.93 \\
\hline $\operatorname{Pr}$ & 5.179 & 10.49 & 8.1 & 8.0 & 10.08 & 10.83 & 8.92 & 9.38 & 9.67 & 10.53 & 8.52 & 12.2 \\
\hline $\mathrm{Nd}$ & 24.04 & 41.27 & 29 & 28 & 39.64 & 42.08 & 32.98 & 33.12 & 34.57 & 39.4 & 31.23 & 40.94 \\
\hline $\mathrm{Sm}$ & 9.06 & 8.852 & 5.0 & 5.9 & 8.55 & 8.936 & 6.38 & 6.42 & 6.71 & 8.55 & 5.26 & 6.66 \\
\hline $\mathrm{Eu}$ & 0.106 & 0.277 & 0.94 & 1.1 & 0.999 & 1.194 & 1.33 & 1.03 & 1.37 & 1.27 & 0.47 & 1.12 \\
\hline $\mathrm{Gd}$ & 8.533 & 6.524 & 4.7 & 5.1 & 7.607 & 7.926 & 6.3 & 6.63 & 6.63 & 8.15 & 4.42 & 5.39 \\
\hline $\mathrm{Tb}$ & 1.849 & 1.025 & 0.81 & 0.94 & 1.367 & 1.397 & 1 & 1.1 & 1.07 & 1.35 & 0.53 & 0.6 \\
\hline Dy & 12.18 & 5.57 & 4.9 & 5.7 & 8.364 & 8.548 & 5.29 & 6.07 & 5.66 & 8.43 & 3.2 & 3.51 \\
\hline Ho & 2.51 & 1.059 & 1.0 & 1.2 & 1.712 & 1.736 & 1.07 & 1.27 & 1.14 & 1.77 & 0.6 & 0.62 \\
\hline $\mathrm{Er}$ & 7.216 & 3.017 & 2.9 & 3.4 & 4.809 & 4.925 & 3.2 & 3.87 & 3.45 & 5.42 & 1.83 & 2.01 \\
\hline $\mathrm{Tm}$ & 1.27 & 0.501 & & & 0.791 & 0.814 & 0.44 & 0.57 & 0.48 & 0.82 & 0.26 & 0.27 \\
\hline $\mathrm{Yb}$ & 7.935 & 3.25 & 3.1 & 3.8 & 4.782 & 4.971 & 2.9 & 3.74 & 3.11 & 5.36 & 1.95 & 1.54 \\
\hline $\mathrm{Lu}$ & 1.185 & 0.484 & 0.44 & 0.56 & 0.697 & 0.723 & 0.44 & 0.57 & 0.47 & 0.81 & 0.29 & 0.24 \\
\hline Hf & 6.159 & 5.794 & 7.9 & 7.4 & 7.605 & 8.169 & 4.76 & 3.67 & 4.98 & 7.44 & 0.24 & 0.14 \\
\hline $\mathrm{Ta}$ & 3.01 & 1.523 & 0.73 & 0.57 & 1.377 & 1.386 & 1.1 & 1.03 & 1.16 & 1.26 & & \\
\hline Th & 40.74 & 31.39 & 18 & 18 & 26.21 & 26.71 & 17.67 & 17.89 & 18.57 & 14 & 23.18 & 23.91 \\
\hline $\mathrm{U}$ & 11.19 & 7.345 & 3.4 & 3.2 & 6.133 & 5.896 & 3.62 & 3.4 & 3.75 & 3.9 & 3.32 & 2.55 \\
\hline $\mathrm{Th} / \mathrm{Yb}$ & 5.13 & 9.65 & 5.80 & 4.66 & 5.48 & 5.37 & 6.09 & 4.78 & 5.97 & 2.61 & 11.88 & 15.52 \\
\hline $\mathrm{Ta} / \mathrm{Yb}$ & 0.38 & 0.47 & 0.24 & 0.15 & 0.29 & 0.28 & 0.38 & 0.27 & 0.37 & 0.23 & & \\
\hline $\mathrm{Nb} / \mathrm{U}$ & 2.51 & 2.43 & 2.94 & 3.00 & 2.64 & 2.33 & 4.48 & 4.17 & 4.55 & 4.02 & 6.74 & 5.80 \\
\hline
\end{tabular}

TH-22, TH-25/3 - Rhyolites, Mang Yang area; DL-509, DL-510 - dasite, Chu Prong area; DN-1, DN-3 - Rhyolites, Hoanh Son area; T1142, T1146, T1150 - dasite and rhyolite, H321/92 - granite-granophyre of Song Ma area. ZAC-3, ZAC-8 - granites, Van Canh area (from Nguyen Xuan Bao, 2001).

Fig. 2-D1-2). Their major differences are depletions of $\mathrm{Eu}, \mathrm{Ba}, \mathrm{Ti}$, and enrichments in HREE of the rocks from the Mang Yang formation in comparison with those from the Song Ma and Hoanh Son areas. Their concentrations and distribution patterns are similar to those of Early Triassic granites (Fig. 2-C and D). Enrichment in $\mathrm{K}, \mathrm{Rb}, \mathrm{Th}, \mathrm{U}$, as well as depletion of $\mathrm{Ba}$,
$\mathrm{Sr}, \mathrm{Nb}, \mathrm{Hf}$, indicates genetic similarities between those intrusive rocks and volcanic ones. The rocks from the Mang Yang formation show relatively low ${ }^{87} \mathrm{Sr} /{ }^{86} \mathrm{Sr}$ ratios $(0.7054,[19])$, similar to the above-mentioned calc-alkaline granitoids. However, the hypabyssal granite of the Hoanh Son area presents higher ${ }^{87} \mathrm{Sr} /{ }^{86} \mathrm{Sr}$ ratios (0.713, [17]), indicating crustal contamination (Table 5) 
Table 5

Isotopic characteristics of the Indosinian magmatic rocks

Tableau 5

Signature isotopique des roches magmatiques indosiniennes

\begin{tabular}{lllccc}
\hline Sample & ${ }^{87} \mathrm{Sr} /{ }^{86} \mathrm{Sr}$ & ${ }^{143} \mathrm{Nd} /{ }^{144} \mathrm{Nd}$ & $\varepsilon_{\mathrm{Nd}}$ & ${ }^{206} \mathrm{~Pb} /{ }^{204} \mathrm{~Pb}$ & ${ }^{207} \mathrm{~Pb} /{ }^{204} \mathrm{~Pb}$ \\
\hline DL556 & 0.704824 & 0.512714 & 6.00 & 18.080 & 15.505 \\
DL533 & 0.705884 & 0.512467 & 1.18 & 18.446 & 15.584 \\
DL544 & 0.707055 & 0.512136 & -5.27 & 18.585 & 15.611 \\
D1542 & 0.706432 & 0.512512 & 2.06 & 18.377 & 15.565 \\
DL043 & 0.705630 & 0.512311 & -0.48 & 18.376 & 15.669 \\
DL1606 & 0.709463 & 0.512108 & -4.45 & 18.947 & 15.669 \\
4-78a & 0.77249 & 0.511958 & -13.3 & & 38.324 \\
4-63b & 0.80728 & 0.512114 & -10.2 & & 38.324 \\
726001/1 & 0.78652 & 0.512116 & -10.2 & & \\
\end{tabular}

DL556, DL533; DL544, DL542 - andesite and dacite of the Dak Lin formation; DL043, DL1606 - gabbrodiorite and diorite of Que Son complex (from [38]); Peraluminous granites: 4-78a - Hai Van massif, 4-63b - Ba Na massif, 726001/1 - Tra My massif (from [25]).

\section{Evolution of Permo-Triassic magmatism and Indosinian orogeny}

\subsection{The Permo-Triassic magmatism of the Truong Son belt is associated with the Indochina/North Vietnam-South China amalgamation}

Geochemical and isotopic significances of the Late Palaeozoic-Early Mesozoic magmatic associations of the Truong Son belt indicate that they represent a full magmatic evolution trend of an active continental margin in relation to the Indochina (IC)/North Vietnam-South China (NV-SC) amalgamation. Presence of andesite in the Dak Lin and Song Da formations is a strong indication of the onset of a subduction process [42-44]. Such formations were considered as volcanic-arc andesites [5]. According to their geochemical and isotopic significance, which were described above, the andesites and calc-alkaline granitoids of the Dien Bien and Ben Giang-Que Son complexes are products of an active continental margin magmatism $[40,42,43]$. The duration of the calcalkaline magmatism is relative long, from the Late Permian to the Middle Triassic (270-245 Ma). The similarities between calc-alkaline granitoids and two remote segments (Dien Bien complex in the northeastern segment and Ben Giang-Que Son complex in the northern Kontum Uplift) strongly support the conclusion that they are both products of the same magmatism process in relation to the (IC)/(NV-SC) amalgamation. It is noteworthy that, during the Cenozoic, the IC block was displaced to the southeast and rotated $60-90^{\circ}$ clockwise $[8,28]$, so that the reconstructed subduction zone might connect three segments of the Truong Son belt.
In addition, Permo-Triassic granitoids are not only present to the west of the Po Ko sub-longitudinal fault zone, but also to the east of this fault zone (northern margin and on the Kontum Uplift). Similar distributions of Middle Triassic volcano-plutonic felsic rocks (the Mang Yang Formation and Van Canh complex), as well as post-collision lamprophyre dykes, are recorded in both sides of the Po Ko fault zone (Fig. 1; III) $[38,44]$. Thus, the presence of a west-impinged subduction zone along the Po Ko fault zone [12] in Permian-Triassic times is hard to prove. Moreover, detailed researches on mafic-ultramafic rocks along the Po Ko zone (Plei Wek formation, after [19]) could exclude the ophiolitic affinity of this formation [24].

The collision between (IC) and (NV-SC) due to the closure of Palaeotethys had led to the formation of peraluminous granite (Truong Son and Hai Van complexes). Compositionally, these granites are similar to syn-collision granites. Their ages of formation are still discussed. In the central segment, peraluminous granite intrusions such as Kim Cuong and Dong Hoi were considered of Carboniferous age [5,44]. The ages of the $\mathrm{Ba} \mathrm{Na}$ intrusion are 245-248 $\mathrm{Ma}(\mathrm{U}-\mathrm{Pb})[21,22]$. The age of the $\mathrm{Pu} \mathrm{Si}$ Lung peraluminous granites of the northeastern segment is $259 \mathrm{Ma}$ ( $\mathrm{Rb}-\mathrm{Sr}$, [18]). The similarities of rock types, mineral composition, as well as geochemical and isotopic characteristics of the peraluminous granites along the Truong Son belt, indicate that the intrusions are all related to the same Early Triassic magmatism. Coeval with the peraluminous granites, a number of gabbro-pyroxenite intrusions (Cha Van Complex, not in this article) exhibit calcalkaline affinity [1] and an age of $243 \mathrm{Ma}$ [19], like the monzogabbros and alkaline lamprophyres [38]. These igneous rocks are scattered all over the Kontum Uplift 
and its northern and western margins. The formation of mafic-ultramafic intrusions under a compressional tectonic regime is a typical feature of the PermianTriassic magmatic activities in eastern Indochina. In previous researches, intrusions of gabbro-pyroxenite, monzogabbro and peraluminous granites are considered as collision bimodal gabbro-granite association $[5,10]$. However, the mafic-ultramafic intrusions are spatially associated with calc-alkaline granitoids (Ben GiangQue Son complex). The association of mafic intrusions with volcanic arc/continental margin igneous rocks are recorded in different folding belts, such as the Central Asian fold belt [2]. The formation of peraluminous granites along the Truong Son belt is correlated with the collision between the IC and NV-SC blocks.

When the compressional regime that was formed by collision between the IC and NV-SC blocks was changed into an extensional regime on the continental margins, the igneous activity is represented by hypabyssal felsic volcano-plutonic association spreading out over the Truong Son belt. Their petrography, as well as geochemical and isotopic compositions, implies that they are typical post-collisional associations $[11,38]$. The differences in potassium contents from the north to the south of the central segment might represent local variations of the magma in relation to their distance to the Kontum ancient continental core. The formation ages of volcano-plutonic rocks of this association are not well determined. On the geological map scale 1:500,000, they are grouped into a Middle to Late Triassic formation [32]. Nevertheless, our Ar-Ar age of phlogopite in the minette dyke that intersects the Mang Yang trachyrhyolite in the Dak Long area (west of the Kontum Uplift) yields 246-240 Ma [44], implying that the Indosinian Orogeny might end earlier, probably in Early to Middle Triassic times. This age is coeval with deformation activities (248-233 Ma) along the Po Ko fault zone to the west, Tam Ky-Phuoc Son, and Song Ma to the north, as well as in the 'core' of the Kontum Uplift [12,14].

There are number of hypothesis about the plunged direction of the subduction in relation to the IC/NV-SC amalgamation: southward [9,15], northwestward [45], or declining northward [12]. Based on the distribution of calc-alkaline granitoids (Dien Bien complex), as well as of post-collision volcanic and hypabyssal rocks (Dong Trau Formation and Song Ma complex) in the South of the Song Ma ophiolite belt, we agree with the interpretation of Lan et al. [11] that the subduction of the Palaeotethys under the northern margin of Indochina occurs in Permian-Triassic times. This model seems to be not adapted to the distribution of the
Permo-Triassic magmatic rocks in the southeastern segment of the Truong Son belt, and it needs more detailed research.

\subsection{Indosinian characteristics of the Permo- \\ Triassic magmatic activities at the eastern margin of Indochina}

Firstly, the Indosinian magmatism is characterized by widespread peraluminous granites; it was derived from crustal sources. The second characteristic in the Indosinian orogeny is characterized by the presence of alkaline mafic intrusions at the early stage (monzogabbro, not included in this paper) and ultrapotassic lamprophyres (minette) at the latest stage in the Kontum Uplift, as well as in its northern and western margins. In the formation of potassic and ultrapotassic lamprophyres, the metasomatism of the lithospheric mantle and subduction-derived fluid play an important role [41]. In the Central Asia Fold Belt (Tianshan-Altai), similar Triassic alkaline lamprophyres (245-236 Ma) result from the interaction between the plumes of the lithospheric mantle and/or of the lower crust [48].

\subsection{Indosinian magmatism and the southern margin of the NV-SC Block}

The Permo-Triassic magmatism in northern Vietnam is widespread. Its coeval activities with those from the Truong Son belt (Indosinian) have put forward a question: are these formations also products of the Indosinian magmatism? The first example is the Song Da rift, northwestern Vietnam. Some authors considered that mafic-ultramafic formations of Song Da are relics of a newly built oceanic crust [13], or ophiolite constituents [46,47], and that closing of the Song Da rift took place in Late Triassic [26] due to the Indosinian orogeny. With the northward [12] or northeastward [45] subducting direction of the Palaeotethys, the Song Da formation is interpreted as resulting from an intraplate or back-arc extension [16]. Detailed investigation on geochemistry and isotopic characteristics of the volcano-plutonic mafic-ultramafic associations of the Song Da shows that they are products of intraplate magmatism that were closely related to the Emeishan Large Igneous Province (LIP) $[3,35,38]$. In addition, volcano-plutonic mafic-ultramafic associations in folding structures of East Bac Bo are products of mantle plume (Emeishan) impacts on a distinct lithospheric mantle [36-39]. Thus, according to this point of view, the Indosinian magmatism is only present along the Truong Son fold belt. 


\section{Conclusions}

The detailed study of Permo-Triassic intermediatefelsic volcano-plutonic and plutonic associations along the Truong Son fold belt demonstrates the homogeneity of the active continental margin magmatism in relation with the Indosinian orogeny in eastern and southeastern Indochina, due to the subduction of the Palaeotethys oceanic crust underneath its margin at the Song Ma suture.

The successive stages of the magmatic evolution are clearly distinguishable: calc-alkaline volcano-plutonic association of the subduction stage (Late PermianEarly Triassic), syn-collision peraluminous granite (Early Triassic), and alkaline post-collision volcanoplutonic association (Middle Triassic). Relevant formation ages of post-collision granites indicate that the Indosinian orogeny ended in Early to Middle Triassic times. Its echo probably extends to the Late Triassic, but additional studies are needed. A specific Indosinian characteristic is the strong crust-mantle interaction, in which the role of crustal contamination was weak at the early stage, strongest during the syn-collision stage, whereas metasomatism by subduction-derived fluid was predominant at the latter one, especially in the regions that have a thick and old crust (Kontum Uplift). The Indosinian magmatism is represented neither at the margin of NV-SC, nor in the eastern Bac Bo.

\section{Acknowledgements}

The authors would like to thank their colleagues of the Department of Magmatism-IGS-VAST for their cooperation on the field and in the course of the investigations.

Thanks are also given to Profs. C. Lepvrier and H. Maluski for their support, to Profs. B. Barbarin, B. Deruelle and M. Petit for critical corrections and recommendations. This paper was finished under the financial support of Projects Nos. 708706, 707806 and 707906.

\section{References}

[1] P.A. Balykin, G.V. Polyakov, Tran Trong Hoa, Ngo Thi Phuong, Hoang Huu Thanh, Tran Quoc Hung, Bui An Nien, Pham Thi Dung, T.E. Petrova, Early Mesozoic complexes of differentiated gabbroids in the North and Central Vietnam, Geology, Ser. B 28 (2006) 1-19.

[2] V.I. Bognibov, A.E. Izokh, G.V. Polyakov, Composition and geodynamic settings of formation of titanium-bearing ultramafic-mafic massifs in the Central Asian Fold Belt, Russ. Geol. Geophys. 41 (8) (2000) 1049-1062.
[3] S.L. Chung, T.Y. Lee, C.H. Lo, P.L. Wang, C.W. Chen, N.T. Yem, T.T. Hoa, Wu Genyao, Intraplate extension prior to continental extrusion along to Ailaoshan-Red River Shear Zone, J. Geol. 25 (4) (1997) 311-314.

[4] Chung S.L., Lan C.Y., Lo C.H., Lee T.Y., Wang T.Y., Tran Trong Hoa, Hoang Huu Thanh, Tran Tuan Anh. The Indosinian orogeny and closure of eastern Paleo-Tethys: amalgamation between the Indohina and South China blocks in the Early Triassic, in GEOSEA 98, Malaysia, 1998 pp. 17-19 (abstract).

[5] Dao Dinh Thuc, Huynh Trung (Eds.), Magmatic formations of Vietnam, Sci. \& Tech, Publ. House, Hanoi, 1995.

[6] Dinh Ngoc Thuan. Geological characteristics of the basement rocks in Bach Ho deposit, Geology master thesis 2004 (in Vietnamese).

[7] A.E. Dovjikov (Ed.), Geology of North Vietnam, Science and Technics Publishing House, Hanoi, 1965 (in Vietnamese).

[8] Geissman J.W., Chen L., Yin J., Burchfiel B., Paleomagnetic Data Bearing on Tectonic Rotations in Northern Indochina, South of the Ailao Shan Shear Zone, Abstr. AGU, 2001.

[9] C.S. Hutchison, Geological evolution of South-East Asia, Mono. Geol. Geophys. 13 (1989) 1-368.

[10] Izokh E.P., Dovjikov A.E., General schema of magmatism in Vietnam, J. Geol. Maps, No. 50, 1981.

[11] Lan C.Y., Chung S.L., Tran Trong Hoa, Tran Tuan Anh, Geochemical and $\mathrm{Sr}-\mathrm{Nd}$ isotopic characteristics of Permo-Triassic arc magmatism, northern Vietnam, Res. Abstr. 5 03074, EGS, 2003.

[12] C. Lepvrier, H. Maluski, Vu Van Tich, A. Leyreloup, Phan Truong Thi, Nguyen Van Vuong, The Early Triassic Indosinian orogeny in Vietnam (Truong Son belt and Kontum massif); implications for the geodynamic evolution of Indochina, Tectonophysics 393 (2004) 87-118.

[13] Le Duy Bach, Ngo Gia Thang, Phanerozoic ophiolites in Indochina, in: Proc. Int. Symp. Geol. of SEA and adjacent areas, J. Geol. B 5-6 (1995) 212-221.

[14] Maluski H., Lepvrier C., Leyreloup A., Vu Van Tich, Phan Truong Thi, 2002. Late-Permian-Early-Triassic thermotectonism in Vietnam (Truong Son belt and Kontum massif), geodynamic implications, IGCP 430 Worshop H: Mantle responses to Tethyan closure, Halong Bay, Vietnam, Abstract (36 p.).

[15] Y.G. Morgunov, Basic features of the tectonics of North Vietnam, Int. Geol. Rev. 12 (1970) 1333-1345 (translation from Russian).

[16] Nguyen Hoang, Nguyen Dac Lu, Nguyen Can, Paleozoic volcanic rocks in the Song Da Structure: Mantle origin and dynamics, J. Geol., Ser. A 283 (2004) 7-8 \& 10-18 (in Vietnamese).

[17] Nguyen Van Thanh, Nguyen Duc Thang, Rb-Sr age of volcanoplutonic rocks from Hoanh Son area, J. Geol., Ser. A 250 (1-2) (1999) 15-17.

[18] Nguyen Van Thanh, Pham Huy Hoc, Le Hung, New date on the $\mathrm{Rb}-\mathrm{Sr}$ isotopic dating of granitoids of the $\mathrm{Pu} \mathrm{Si}$ Lung complex, in Proc. Scientific Conference: 60th annivesary of Vietnam Geology, October 2005, pp. 221-225 (in Vietnamese).

[19] Nguyen Xuan Bao (Ed.), Tectonics and Metallogeny of South Vietnam, Geological Expedition No 6, Department of Geol. \& Min. of Vietnam, 2001 (in Vietnamese).

[20] Nguyen Xuan Tung, Tran Van Tri (Ed.), Geological formations and geodynamics of Vietnam, Science and Technics Publishing House, Hanoi 1992 (in Vietnamese).

[21] Nguyen Trung Minh, Results of Rb-Sr dating of Ba Na granitic massif (central Vietnam), J. Geol., Ser. A 277 (2003) 68-71. 
[22] Nguyen Trung Minh, Age of Bana granite (central Vietnam) determined by U-Pb isotopic method, J. Geol., Ser. A 287 (3-4) (2005) 20-25.

[23] J.A. Pearce, N.B. Harris, A.G. Tindle, Trace element discrimination diagrams for the tectonic interpretation of granitic rocks, J. Petrol. 25 (1984) 956-983.

[24] Pham Thi Dung, Tran Trong Hoa, Ngo Thi Phuong, Tran Tuan Anh, Bui An Nien, Characteristics of mineral composition (olivine, pyroxene, chrome spinel) of ultramafic intrusions located in the margin of the Kontum Uplift, J. Geol., Ser. B 28 (2006) 47-57.

[25] Phan Luu Anh, Tran Trong Hoa, A.G. Vladimirov, Tran Tuan Anh, The forming condition of Hai Van and $\mathrm{Ba} \mathrm{Na}$ granitoid on the basis of new data of rare element and isotopes, J. Sci. Earth 17 (4) (1995) 151-155.

[26] A.M.C. Sengör, K.J. Hsu, The Cimmerides of eastern Asia: history of the eastern end of Paleo-Tethys, Mem. Soc. geol. France 147 (1984) 139-167.

[27] S.S. Sun, W.F. McDonough, Chemical and isotopic systematics of oceanic basalts implications for mantle composition and processes, in : A.D. Saunders, M.J. Norry (Eds.), Magmatism in the Ocean basins, 42, Geol. Soc. Lond. Spec. Publ., 1989, pp. $313-345$

[28] P. Tapponnier, R. Lacassin, P.-H. Leloup, U. Sharer, Zhong Dalai, Liu Xiaochan, Ji Shaocheng, Zhang Liangshang, Zhong Jaiyou, The Ailao Shan-Red River metamorphic belt: Tertiary left-lateral shear between Indochina and South China, Nature 343 (1990) 431-437.

[29] B. Taylor, D.E. Hayes, Origin and history of the South China Sea Basin. The tectonic and geologic evolution of Southeast Asian seas and islands, part 2, in : D.E. Hayes (Ed.), Geophysical Monograph 27, American Geophysic Union, Washington, 1983, pp. $23-56$

[30] R.N. Thompson, M.A. Morrison, G.L. Hendry, S.J. Parry, An assessment of the relative roles of crust and mantle in magma genesis: An elemental approach, Philos. Trans. R. Soc. A310 (1986) 549-590.

[31] Tong Duy Thanh and Vu Khuc (Eds.), Stratigraphic units in Vietnam, Hanoi National University Publ. House, 2005 (in Vietnamese).

[32] Tran Đuc Luong, Nguyen Xuan Bao (Chief-Editors), 1989, Geol. Map of Vietnam on 1:500 000, Geol. Surv. Vietnam, Hanoi.

[33] Tran Thanh Hai, Nguyen Van Nguyen, Tectonic setting of intrusive complexes in an area adjacent to Muong Lay Town, Dien Bien Province, Sci.-Tech. J. Min. Geol. 14 (4) (2006) 43-52.

[34] Tran Trong Hoa, Phan Luu Anh, Tran Tuan Anh, Chemical composition of biotites in granitoid and their implications in rock classification, Geology-Resources, Publ. Sci. \& Tec 1 (1996) 112-123 (in Vietnamese).
[35] Tran Trong Hoa, Subdivision and correlation of Permian-Triassic basaltoid associations in the Song Da structure (NW Vietnam), J. Geol., Ser. B 19-20 (2002) 22-30.

[36] Tran Trong Hoa, Tran Tuan Anh, A.E. Ngo Thi Phuong, G.V. Izokh, P.A. Polyakov, Balykin, Ching-Ying Lan, Hoang Huu Thanh, Bui An Nien, Pham Thi Dung, Gabbro-syenite associations of East Bac Bo structures: evidences of intra- plate magmatism? J. Geol., Hanoi, Ser. B 23 (2004) 12-25.

[37] Tran Trong Hoa, Tran Tuan Anh, Ngo Thi Phuong, Pham Thi Dung, Tran Viet Anh, Permian-Triassic basalt-rhyolite associations of the Song Hien structure, NE Vietnam, J. Sci. Earth 26 (4) (2004) 392-405.

[38] Tran Trong Hoa, Tran Tuan Anh, Ngo Thi Phuong, Pham Thi Dung, Tran Viet Anh, 2005. Permian-Triassic magmatism of Vietnam and their potential of associated precious metals $(\mathrm{Pt}$, $\mathrm{Au}$ ) in Proceedings of the scientific conference: 60th annivesary of Vietnam Geology (10-2005): 63-79 (in Vietnamese).

[39] Tran Trong Hoa, Intraplate magmatism in North Vietnam and metallogeny, Dr. Sci. dissertation, Novosibirsk, 2007 (in Russian)

[40] Tran Tuan Anh, Tran Trong Hoa, Permian-Triassic Calc-Alkaline granitoids on the marginal of Truong Son microblock, Geology-Resources, Pub. Sci. \& Tec. 2 (1996) 100-108.

[41] Tran Tuan Anh, Mai Kim Vinh, Tran Trong Hoa, Ngo Th Phuong, Tran Viet Anh, The Mineralogy of phlogopites from lamprophyres of central Vietnam: implication for the magma's evolution, J. Geol., Ser. B 23 (2004) 79-88.

[42] Tran Tuan Anh, Tran Trong Hoa, Hoang Huu Thanh, Geochemical significances of Carboniferous-Permian intermediate volcanism of South Vietnam, J. Geol., Ser. B 26 (2005) 18-27.

[43] Tran Tuan Anh, Tran Trong Hoa, Nguyen Viet Y, 2005b. Forming conditions $(\mathrm{P} / \mathrm{T})$ of granitoid of Dien Bien and Song Ma complexes-NW Vietnam, J. Sci. Earth 27 (3) 213-222 (in Vietnamese)

[44] Tran Tuan Anh, Tran Trong Hoa, Age constrains on the lamprophyre's petrogenesis of South-Central Vietnam, J. Geology, Ser. B 27 (2006) 23-29.

[45] Tran Van Tri (Ed.), Geology of Vietnam, the North part, Science and Technics Publishing House, Hanoi, 1977 (in Vietnamese).

[46] Trinh Xuan Cuong, Characteristics of the basement petroliferous rocks in Bach Ho deposit, J. Pet. Gas 5 (2002) 2-18 (in Vietnamese).

[47] Van Duc Chuong, Ophiolite zones in Vietnam, Geol. Resour. 2 (1996) 41-52.

[48] Vrublevski V.V., Gertner I.F., Polyakov G.V., Izokh A.E., Krupchatnikov V.I., Travin A.V., Voichenko N.N., Ar-Ar age of lamproite dykes from Chyuski complex, Gornyi Altai. Report of RAS, Vol. 399, No. 4, 2004, pp. 516-519.

[49] M. Wilson, Igneous petrogenesis - A global tectonic approach, Published by Chapman \& Hall, 1989. 